\begin{tabular}{|l|c|c|c|c|}
\hline $\begin{array}{l}\text { Cuadernos de Investigación Geográfica } \\
\text { Geographical Research Letters }\end{array}$ & 2020 & N $^{\circ} 46(2)$ & pp. 447-476 & eISSN 1697-9540 \\
\hline
\end{tabular}

\title{
STRUCTURAL HEALTH ASSESSMENT OF PUENTE DEL INCA NATURAL MONUMENT USING THE INTEGRATION OF INSTRUMENTS AND TECHNOLOGIES
}

\author{
E. LANNUTTI ${ }^{1 *}$, M.G. LENZANO ${ }^{1}$, J. BARÓN ${ }^{2}$, S. MORAGUES ${ }^{1}$, L. LENZANO ${ }^{1}$ \\ ${ }^{1}$ Instituto argentino de Nivología, Glaciología y Ciencias Ambientales, CONICET-MENDOZA, \\ Av. Ruiz Leal s/n, Parque General San Martín, Ciudad de Mendoza, Argentina. \\ ${ }^{2}$ Instituto de Estudios del Ambiente y Recursos Naturales (IDEARN), \\ Universidad Nacional de Cuyo, Mendoza, Argentina.
}

\begin{abstract}
Puente del Inca is a natural monument standing over the Cuevas river in Mendoza, Argentina. The bridge currently exhibits structural deterioration due to natural and anthropic factors. This article seeks to offer a contribution to the conservation and restoration works of Puente del Inca by integrating instruments and technologies that allow the assessment of the health state of the natural bridge. The study relied on visual inspection, accretion-erosion rate measurements, hydrothermal flow characterization, ground-penetrating radar, soil dielectric sensor, Global Navigation Satellite System, laboratory testing, Structure from Motion, the Finite Element Method and ambient vibration testing. The results show that the morphology and health of the natural bridge depend on the dynamic balance between the erosion and the geobiological system intervening in the formation of the travertine constituting the natural bridge. The computational structural modeling demonstrates that there is a controversy between the benefit of irrigating the geological formation with thermal water and the loss of stability of the bridge under saturation conditions. Nevertheless, a continuous monitoring and an efficient administration of thermal water may ensure the deceleration of most of the erosive processes as well as the improvement of the geobiological system health.
\end{abstract}

Evaluación de la salud estructural del monumento natural Puente del Inca mediante la integración de instrumentos y tecnologías

RESUMEN. Puente del Inca es un monumento natural situado sobre el río Cuevas en Mendoza, Argentina. Actualmente, el puente presenta un deterioro estructural debido a factores naturales y antrópicos. Este artículo busca contribuir con los trabajos de conservación y restauración de Puente del Inca mediante la integración de instrumentos y tecnologías que permitan evaluar el estado de salud del puente natural. El estudio está basado en inspecciones visuales, mediciones de tasa de acreción y erosión, caracterización del flujo hidrotermal, Georradar, mediciones dieléctricas del suelo, Global Navigation 
Satellite System, ensayos de materiales, Structure from motion, método de elementos finitos y pruebas de vibración ambiental. Los resultados muestran que la morfología y la salud del puente natural dependen de un equilibrio dinámico entre los procesos erosivos y geobiológicos que intervienen en la formación del travertino que constituye el puente natural. El modelo numérico estructural computacional demuestra que existe una controversia entre el beneficio de irrigar con agua termal la formación geológica y la pérdida de estabilidad del puente en condiciones de saturación de agua. Sin embargo, un monitoreo continuo y una administración eficiente del agua termal pueden asegurar la desaceleración de la mayoría de los procesos erosivos así como la mejora de la salud del sistema geobiológico.

Key words: Natural bridge, Puente del Inca, geobiological system, computational structural modeling.

Palabras clave: puente natural, Puente del Inca, sistema geobiológico, modelo estructural computacional.

Received: 10 October 2019

Accepted: 18 February 2020

*Corresponding author: Esteban Lannutti, Instituto argentino de Nivología, Glaciología y Ciencias Ambientales, CONICET-MENDOZA, Av. Ruiz Leal s/n, Parque General San Martín, Ciudad de Mendoza, Argentina.E-mail address: elannutti@mendoza-conicet.gob.ar.

\section{Introduction}

Current scientific studies require robust, precise and cost-effective data acquisition and management techniques. Many of the techniques and methods in use today do not simultaneously meet all of these requirements. In response to this, the multidisciplinary approach based on an integration of measurement techniques and processing methods, is being increasingly used, due to the efficiency of its results, particularly in studies involving complex multicausal processes, such as those carried out in Geology, Engineering and Geomatics (Wiese and John, 2003; De-ren, 2007; Di Crescenzo and Santo, 2007; Shen et al., 2010; Salvini et al., 2011; Lorenzoni, 2013; Masciotta et al., 2016; López et al., 2017; among others). Likewise, in these areas of knowledge, the construction of computational models has gained greater momentum, as they afford the possibility to infer/predict the behavior of complex systems and thus evaluate/experiment with different scenarios in efficient, time- and cost-effective ways. To attain significant levels of reliability and robustness in the solutions of these models, they need to be based on a methodology that is oriented towards an efficient and accurate management of the elements and rules of the system, of the input and internal variables and on the use of result validation processes. In line with this, it is important to implement methods used in control and process engineering in the present study and numerical modeling. In this context, computational modeling offers growing potentialities, due to the level of detail, economy and speed reached in its results as 
compared to analytical solutions (Slingerland and Kump, 2011). As computational simulation is an approximate imitation of real world systems, simulations need to be optimized as needed with a view to the application of the anticipated model (Carson, 2002). Thus the implementation of specific validation processes is relevant to the modeling process, as it enhances the precision and reliability of the results obtained in the simulations.

The natural Puente del Inca Bridge (PI hereafter) is an important monument for the region and it is part of the cultural identity of Mendoza, since it integrates historical, architectural, scientific, and natural heritage value. PI is in a state of deterioration (Kittl, 1941; Monteverde, 1967; Ramos, 1993; Rimoldi, 1993; Rubio et al., 1993; Lannutti, 2017) due to the effect of natural and anthropic processes. That is why it is necessary to study and contribute to a better understanding of the factors conditioning its stability. As explained by Lannutti (2017), the morphology and integrity of PI are defined by the result of the dynamic interaction between the erosive processes that weaken its structure and the deposition of hydrothermally-originated travertine that thickens and strengthens the bridge. Given the complexity and number of processes intervening in the resulting balance (fluvial and eolic erosion, meteorization, biological, physical and chemical processes of travertine deposition and thermal water material cementation, variation in thermal water flow, etc.), the efficient, accurate study of the integrity of PI requires a multidisciplinary approach. In addition, the integral management of techniques and technologies that may offer a foundation and input data for the development of a simulation structural numerical model is representative of the bridge.

The goal of this study is to apply a methodology based on the integration of instruments, methodologies, technologies and disciplines that contribute to the assessment and identification of favorable measures to preserve and restore the natural monument. In order to achieve this aim, the integrity of PI, the geobiological system, the internal structure, the surface deformations, the mechanical characteristics of the material, the 3D geometry, and the construction and validation of a structural numeric model were studied and defined. The study applied Visual Inspection (VI) to assess the integrity of PI, Accretion-Erosion Rate measurements (AER) and Hydrothermal Flow Characterization (HFC) to study the geobiological system, Ground Penetrating Radar (GPR) and Soil Dielectric Sensor (SDS) to evaluate the internal structure, Global Navigation Satellite System (GNSS-GPS) to measure the surface deformations, Laboratory Testing (LT) to examine the material, Structure from Motion (SfM) to generate the 3D geometry and Finite Element Method (FEM) and Ambient Vibration Testing (AVT) for the construction and validation of the Puente del Inca Structural Numeric Model (PISNM).

\section{Site description and historical background}

Puente del Inca is located in the district of the same name, at $32^{\circ} 49^{\prime} 34$ " S - $69^{\circ}$ $54{ }^{\prime} 41^{\prime \prime} \mathrm{W}, 183 \mathrm{~km}$ away from the city of Mendoza, Argentina (Fig. 1). It forms a natural arch over the Cuevas River, one of the headwater tributaries of the Mendoza River, in the Andes Mountain Range. It is a Protected Natural Area and it is part of the Qhapaq Nan Andean Roadway System, a recently designated UNESCO World Heritage Site. 


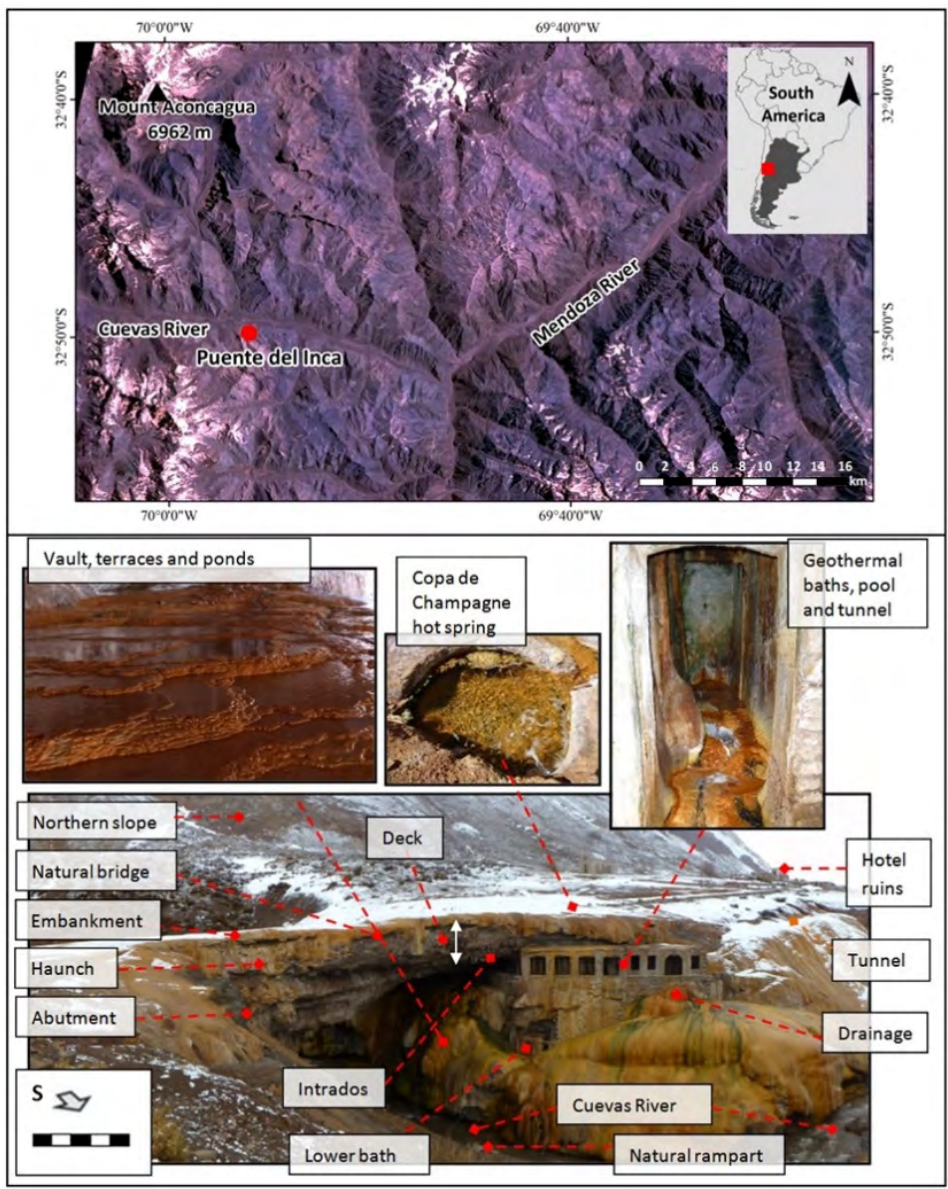

Figure 1. Location map of the relative position and general view of the main constituent parts of Puente del Inca natural monument.

The earliest mentions of the bridge are attributed to Lizárraga in the $16^{\text {th }}$ century, Ovallein in 1646, and Concolorcorvo in 1776 (Lannutti, 2017). In the $19^{\text {th }}$ century, several artists, scholars, and travelers produced papers, studies and reports during their journeys across the region, with Darwin (1838) standing out among them. Early in the $20^{\text {th }}$ century, with the construction of the trans-Andean railway, the Hoteles Sudamericanos Company built a modern hot springs baths hotel in the vicinity of the bridge (Fig. 1). The baths were built on the terrace, on the right side of the hotel, and attached to the natural structure. They were connected with the hotel by means of a 100-meter long underground tunnel. In 1965, the site was finally abandoned, after a snow avalanche had caused serious damage to the hotel structure. In addition, at the top of the bridge there is a hot spring (Fuente Copa de Champagne (FCC)) that irrigates a large area of the monument. 
For many years, access to the natural structure and the baths - which had not been affected by the avalanche- remained unrestricted, and any visitor could get to the facilities and use them. However, in 1991, PI was officially categorized as an "intangible area" and access was restricted, in line with conservation and safety criteria. Nowadays, the monument is visited by thousands of tourists every year, but it can only be gazed at the northeast side of the river.

\subsection{The natural bridge}

Since the $19^{\text {th }}$ century, a number of authors have analyzed the possible origin of this natural geological formation. From a structural point of view, the theories proposed up to date may be classified according to whether they assume the existence or absence of a base material over which the cementation and deposition of the travertine took place, which, together with the erosive processes, led to the formation of the natural bridge. For further detail on the hypotheses on the origins of the bridge, see Ramos (1993), Fauqué et al. (2009) and Lannutti (2017). In summary, according to Darwin's hypothesis (1838), the material base was provided by the collapse of detritus on a cliff; in Monteverde (1946)-Kittl's (1941) view, it originated in pre-existenting fluvial-glacial conglomeratic banks. Also, in Aguirre Urreta and Ramos's hypothesis (1996), the origin of the bridge can be attributed to the formation of an ice bridge that served as a foundation for the geological formation, whilst Fauqué et al. (2009), relates it to the large detritus flows coming from the mega landslides of the southern slope of Mount Aconcagua deposited in the valley of the Cuevas river. However, according to Sekelj (1944), Dr. Schiller stated in 1907 that the bridge originated without the need for a previous base, but rather was formed by the apposition of material generated by the hot springs from a lateral growth process towards the opposite bank of the Cuevas River.

Even though different hypotheses have been put forward on the formation of PI, all of them include the hot springs in the area as a common factor. As shown in many papers on geothermal environments (Hammer et al., 2007; Veysey et al., 2008; Fouke, 2011; Gandin and Capezzuoli, 2014), hot springs form travertine as a result of the interaction of physical, chemical and biological processes. Therefore, in addition to the mechanism that initiates the formation process, the activity of thermal water produces a geobiological system that generates the travertine deposition and material cementation that form the bridge.

Travertine deposits of hydrothermal origin can be classified according to their morphology as follows: mound, fissure ridge, paludal, cascade, dam, fluvial crust, cemented rudite/clast, lacustrine crust and reef (Pentecost, 2005). In some particular cases, cascade deposits generate natural travertine bridges named Yerköprü (Turkish for land bridge). Table 1 shows examples of Yerköprü around the World. PI could be classified as a Yerköprü, as it shares a number of characteristics with this kind of formation such as cascading thermal springs; a geobiological system; deposition of travertine; a valley with a turbulent river preventing the formation of a dam due to erosive fluvial processes, and the dilution of thermal water, among others. Note that Lannutti (2017) offers a detailed discussion of this classification. 
Table 1. Examples of natural travertine bridges around the World (Yerköprü)

\begin{tabular}{|c|c|c|}
\hline Country & Denomination & Reference \\
\hline Argentina & Puente de Inca & Lannutti, 2017 \\
\hline Armenia & Devils Bridge & - \\
\hline Burma & Gokteik Gorge & La Touche, 1906 \\
\hline Chile & Puente de Tierra & $\begin{array}{l}\text { Cornejo, } 2008 \\
\text { Wilson, } 2013 \\
\end{array}$ \\
\hline China & Small bridges in Southeast China & Pentecost, 2005 \\
\hline France & Pont Naturel L'Argens, Provence & Nicod, 1981 \\
\hline France & Pont Naturel Saint Alyre & Monteverde, 1946 \\
\hline Greece & Zesta Nera Cave & Lazaridis et al., 2005 \\
\hline Morocco & Imi-n-Ifri & - \\
\hline Morocco & God's Bridge & - \\
\hline Peru & Yauli River Bridge & Howard, 1948 \\
\hline Peru & Puente Bello & - \\
\hline Turkey & $\begin{array}{c}\text { Zamanti-Yerköprü } \\
1-2-3\end{array}$ & $\begin{array}{c}\text { Bayari and Kurttas, } 1997 \\
\text { Bayari, } 2002\end{array}$ \\
\hline Turkey & Hadim-Yerköprü & $\begin{array}{c}\text { Bayari, } 2002 \\
\text { Pentecost, } 2005 \\
\text { Polat, } 2011 \\
\end{array}$ \\
\hline Turkey & Diyadin Kudret & Polat 2011 \\
\hline Turkey & Diyadin Köprüçermik & Polat, 2011 \\
\hline Turkey & Delikkaya & Polat, 2011 \\
\hline Turkey & Subatan & Polat, 2011 \\
\hline Turkey & Ermenek-Yerköprü & Polat, 2011 \\
\hline Turkey & Evren-Yerköprü & Polat, 2011 \\
\hline Turkey & Çakıtsuyu-Yerköprü & Polat 2011 \\
\hline United States & Tonto Natural Bridge Arizona & Feth and Barnes, 1979 \\
\hline United States & Fremont Wyoming & Feth and Barnes, 1979 \\
\hline
\end{tabular}

\section{Materials and methods}

As shown in the flowchart in Figure 2, the proposed approaches departed from the study of PI by means of Visual Inspection (VI). Furthermore, Hydrothermal Flow Characterization (HFC) and Estimation of Accretion-Erosion Rates (AER) were carried out. Prospection techniques such as Ground Penetrating Radar/Soil Dielectric Sensor (GPR/SDS) and the Global Navigation Satellite System (GNSS) were also applied to study the bridge's internal structure and measure its surface deformations, respectively. In order to generate the Puente del Inca Structural Numeric Model (PISNM), we include the following items as input parameters: the mechanical parameters of the travertine and the 3D geometry of the structure. In 
addition, the PISNM was developed by the Finite Element Method (FEM) validated trough natural frequencies. Simulations of the structural response of the PI were performed by means of the PISNM.

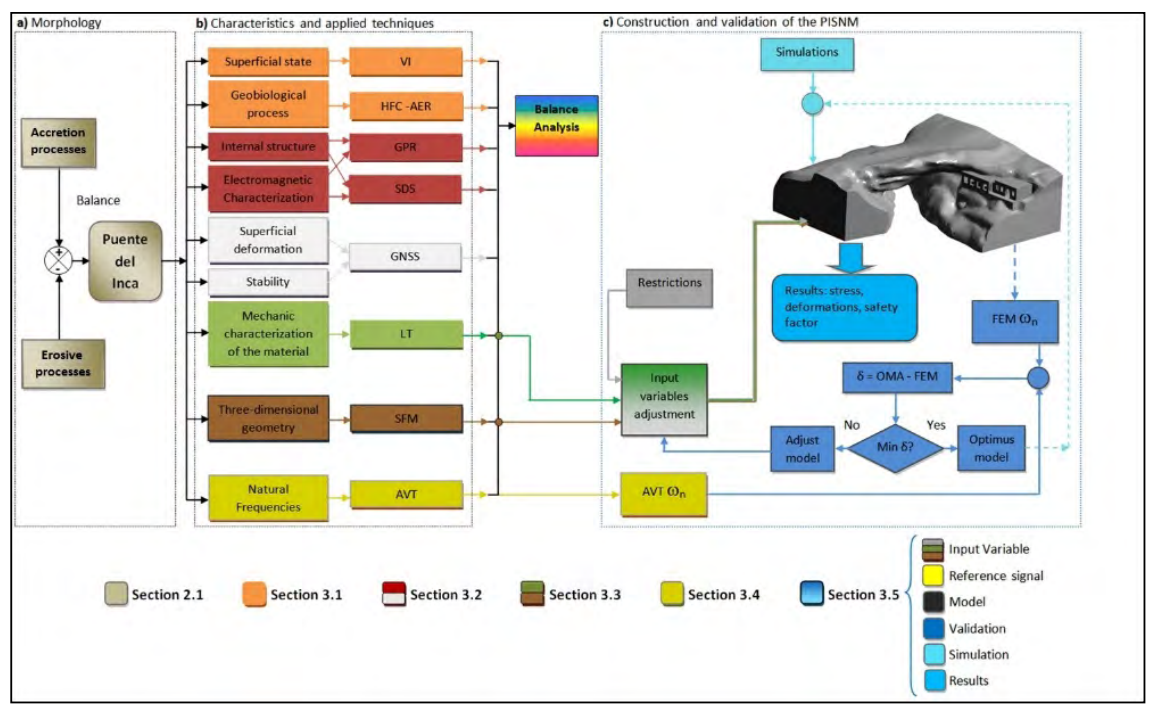

Figure 2. Flowchart displaying the methodology applied in this study: a) The morphology of the geological formation is defined by the result of the balance between the erosive processes and the formation of the travertine deposition. b) Techniques applied to the study of the balance, which define the analysis of PI's integrity and the input variables of the numerical model. Visual Inspection (VI), Hydrothermal Flow Characterization (HFC), estimation of Accretion-Erosion Rates (AER), Ground Penetrating Radar/ Soil Dielectric Sensor (GPR/SDS), Global Navigation

Satellite System (GNSS), Laboratory Testing (LT), Structure from Motion (SfM), Ambient Vibration Testing (AVT) and Finite Element Method (FEM c) Construction and validation of the Puente del Inca Structural Numerical Model (PISNM).

\subsection{Visual inspection and hydrothermal flow characterization}

The visual inspection was preceded by a compilation of bibliographic data which included Kittl (1941), Monteverde (1946), Monteverde (1967), Ramos (1993), Rimoldi (1993), Rubio et al. (1993), Aguirre Urreta and Ramos (1996), Ferrari et al. (2002), Fauqué et al. (2009). Besides, an in situ visual inspection of the relevant elements of the structure (the haunch, abutment and intrados, as shown in Fig. 1) was carried out, in search for potential pathologies and deterioration that may affect its stability.

Then, a hydrothermal flow characterization was performed in order to classify and study the travertine deposits and assess their connection with the geobiological processes intervening in the integrity of PI. To carry out this characterization, PI was first divided into four hydrothermal flows: Fuente Copa de Champagne (FCC), Bath-Drainage-East (BDE), Bath-Drainage-South (BDS), and Tunnel-Hotel-Bath (THB) (see Fig. 3a, b). 
Some of the facies existing in geothermal environments proposed by Fouke (2011) were identified and described in each of these four flows. The characterization was performed in February 2014, taking into account the area, the landscape assessment, the structural incidence, the hydrothermal activity, the qualitative thermal spring flow, the morphology, color, and density of microbial communities, and the relationship between thermal spring flow and area size. Furthermore, a method for the estimation of the accretion-erosion rate was conducted using metric rulers (Fig. 3b). The metric rulers installed measured the surface level changes of every hydrothermal flow over time. A total of 15 rulers were installed (P1-P15, see Fig. 3b), and four sets of measurements were performed for the periods $10 / 22 / 2014,09 / 30 / 2015,12 / 12 / 2015$, and $02 / 22 / 2016$. For further details on both the Visual Inspection and the hydrothermal flow characterization, see Lannutti (2017).

\subsection{PI Internal structure and surface displacements}

\subsubsection{Prospection technique: Ground Penetrating Radar / Soil Dielectric Sensor (GPR/ $S D S)$}

In order to determine whether the material that forms the bridge is homogeneous or it presents fractures, cracks and/or discontinuities it is necessary to study the internal structure of PI in detail. This information may contribute not only to the identification and location of failure points that may compromise the stability of the bridge, but also to the development of a more precise and detailed numerical model of the structure. Note that PI is a protected natural area and it is thus important to apply techniques that can minimize any possible damage on the bridge. Ground-penetrating radar (GPR) is a geophysical method that consists of emitting short electromagnetic pulses that produce good resolution subsurface images as compared to other prospecting methods. It is a nondestructive method of rapid data acquisition/implementation that provides real-time observations, which can be processed in the field to obtain in situ information (Biskup et $a l ., 2005)$. In complex propagation media, such as the structure of PI, where the existence of thermal water in the material may condition the propagation of the GPR signal, it is important to validate the measurements based on the knowledge of the electromagnetic characteristics of the medium. Soil dielectric sensors offer an alternative to validate the GPR results through the determination of the electromagnetic properties of the medium. Both Lambot et al. (2008) and Mahmoudzadeh et al. (2012) previously used this sensor model to successfully validate their GPR results.

We performed GPR measurements along 3 longitudinal profiles and 3 transverse profiles on the bridge surface (Fig. 3a). SIR-3000, a GPR data acquisition unit of Geophysical Survey Systems, Inc., was used for this study in two frequency ranges, namely, $200 \mathrm{MHz}$ with a monostatic model 5106 antenna and 16-80 MHz with a model 3200 multiple low-frequency (MLF) antenna. The topographic correction and location of the profiles were determined using a Trimble 5700 dual-frequency GPS receiver. The A-A' longitudinal profile on Figure 3a was measured at $200 \mathrm{MHz}$, in two different periods and under different humidity conditions (February 2013, with an inactive FCC - February 2014, with an active FCC) in order to assess the influence of hot spring water on the GPR signal. To characterize and study the bridge's internal structure, the 
B-B' and C-C' longitudinal profiles and the D-D', E-E', and F-F' transverse profiles were measured in February 2014 with low-frequency antennas $(20 \mathrm{MHz})$ to obtain better penetration lengths. The GPR profiles were processed using the ReflexW 2D Quick software, while the GPS post-processing was performed by means of the open-source RTKLIB software library (Takasu, 2009).

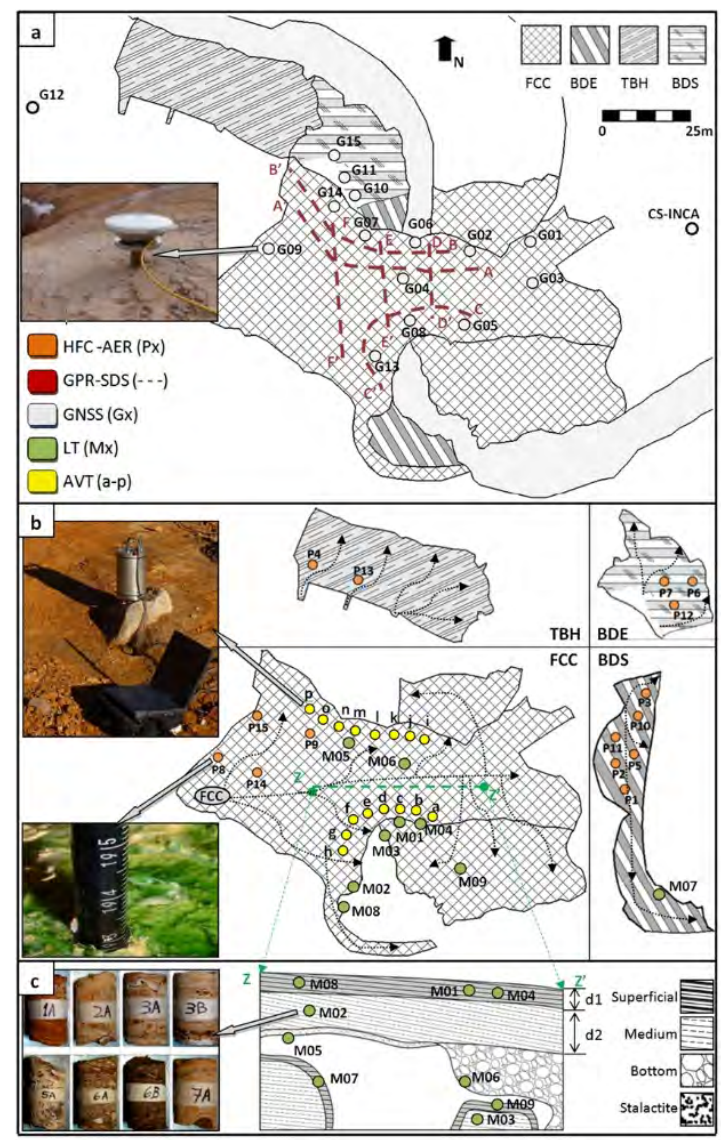

Figure 3. Location maps with information referring to techniques and methodology applied in the study of Puente del Inca indicated with colors: a) location of the four hydrothermal flows classified in the geothermal environment: Fuente Copa de Champagne (FCC), Bath-Drainage-

East (BDE), Bath-Drainage-South (BDS), and Tunnel-Hotel-Bath (THB); GPR profiles (red dotted line) and GNSS (GX/white points) installed on the bridge surface. b) location of AER (PX/ orange points), of rock extraction points for the LT (Mx/green points), and of AVT measurement

(a-p/yellow points). c) schematic drawing and Z-Z' longitudinal cross-section where rock extraction points for the surface-medium-bottom-stalactite layers are shown.

The validation of the ground penetrating radar results was carried out by measuring the complex permittivity and the electrical conductivity of hot spring water with a Hydra Probe (50-MHz) soil dielectric sensor (Seyfried and Murdock, 2004) to determine the 
attenuation and the velocity of the medium. For further details about this section, see Lannutti et al. (2017).

\subsubsection{GNSS measurements}

Monitoring and measuring the surface displacement or deformations of PI is important when it comes to integrally evaluate the stability of the structure in the course of time. Differential GNSS (DGNSS) is a useful and accurate method to auscultate large structures, as it may offer information about their movements and deformations (Marchamalo et al., 2011). This technique enables to measure the displacement of structures in tridimensional directions and may in addition afford millimetric levels of precision by means of carrier phase measurements (Cheng et al., 2002). The precision of these phase measurements mostly depends on the longitude of the baseline and the combination of observables that are used. When the distances between the base and the measurement points are small, it is possible to obtain millimetric precision levels (Galán et al., 2011). Bearing in mind the proximity between the bridge and the Continuously Operating Reference Station (CORS-INCA) ( 100 m) and the high precision required, the DGPS auscultation method was chosen to study and monitor the surface deformation (north, east, up) of PI.

Therefore, a Global Positioning System (GNSS-GPS) network constituted by 15 points located on the surface of PI (Fig. 3a) was installed in order to measure the surface deformations of the structure. 11 points were installed all over the bridge (G01-G02G03-G04-G05-G06-G07-G08-G09-G13-G14), whilst other 3 points (G10-G11-G15) were placed on the roof of the main geothermal baths to measure the building stability and its interaction with the bridge. Note that the last point (G12) was placed $120 \mathrm{~m}$ to the west of the monument since it provides, together with the CORS-INCA, a reference point within the architecture of the network. The measurement equipment includes a stainlesssteel mast (see picture in Fig. 3a), Trimble 5700-NetRs dual-frequency receptors and Trimble Zephyr antennas, and portable supply systems based on solar power. Three annual campaigns (September 2013, October 2014, September 2015) were measured. Each one consisted of 12 hours measurements in each of the 14 points located on the structure, while G12 and CORS-INCA points recorded data for at least 48 hours.

The estimation of the coordinates was based on two post-processing strategies. The first strategy involved calculating the coordinates and velocities of CORS-INCA and the G12 point by means of DGPS dual frequency processing (L1- L2), in 48-hour sessions at 15 -second rates, taking as reference the IGS (International GNSS Service: UNASLPGS-PARC-BRAZ) stations. In the second strategy, CORS-INCA and G12 served as points of reference. Then, the coordinates of the remaining 14 points were estimated for each campaign, by means of single frequency differential processing (DGPS-L1) due to the short distances among the points in the network $(<300 \mathrm{~m})$. The Bernese 5.0 scientific post-processing software (Dach et al., 2007) was used in both strategies. Finally, once the coordinates of each point were obtained for each campaign, the displacement magnitudes were estimated by calculating the differences in the coordinates determined for the first and the two subsequent years. 


\subsection{PISNM input parameters}

\subsubsection{Mechanical laboratory testing}

The mechanical parameters of the material making up PI are one of the input variables for the PISNM. In order to implement the proposed FEM structural model (see Section $3.5)$, it is necessary to define the density (Q), the elasticity modulus (E), Poisson's ratio $(v)$, and the compressive and tensile strengths $(\sigma c, \sigma t)$ of the material. Then, to estimate these parameters, Laboratory Testing was performed on 13 core samples with a diameter size of $54 \mathrm{~mm}$ (1A-2A-3A-3B-4A-5A-6A-6B-7A-7B-8A-8B-9A) obtained from 9 rock samples (M01-M02-M03-M04-M05-M06-M07-M08-M09) from the natural geological formation (Fig. 3b, c). The criteria for extraction site selection rested on the hypothesis that the bridge is mainly composed of four materials or layers, each with different properties (namely, surface, medium, bottom, stalactites. See Fig. 3c) associated with their formation process (for further detail, refer to Lannutti, 2017). It should be noted that there are periods when thermal water ceases to flow from the thermal sources, particularly from the Fuente Copa de Champagne source (see Fig. 1). Then the bridge presents either dryness or water saturation conditions. To obtain the mechanical parameters of the materials that could be taken to be representative of these two conditions, tests were performed on dry and saturated cores. The tests were carried out by Instituto Técnico de Investigaciones y Ensayo de Materiales (ITIEM, Spanish acronym for the Technical Institute for Materials Study and Testing) of the School of Engineering of the National University of Cuyo, Argentina. Destructive (Uniaxial compressive strength, UCS), and non-destructive tests (Ultrasonic Velocity Tests, UVT) were applied.

\subsubsection{SfM: $3 d$ geometric model}

The PISNM needs to be based on an accurate $3 \mathrm{~d}$ geometrical model. Bearing in mind that PI presents a complex asymmetrical geometry, expeditious, quick methods were chosen that could provide robust solutions. Today, computerized vision techniques such as SfM (Structure from Motion) quickly and automatically build detailed 3D models based on a series of optical photographs (Westoby et al., 2012; Smith et al., 2015). This technique offers the advantages of high resolution, low cost, broad field of vision, simplicity and speed (Smith et al., 2015; To et al., 2015). SfM operates under the same parameters as conventional stereoscopic photogrammetry, with the difference that the geometry of the scene, the positions of the camera and the orientation are automatically resolved (Westoby et al., 2012). As a final product, having implemented sophisticated computational vision techniques and photogrammetric algorithms (Smith et al., 2015), 3D structures (dense point clouds) are obtained from temporal and spacial 2D sequences. The output of the SfM stage is a sparse, unscaled 3D point cloud in arbitrary units along with camera models and poses (Smith et al., 2015). Thus, it is necessary to scale and georeference the 3D reconstruction obtained by means of Ground Control Points (GCPs) of known coordinates previously located on the site.

For the present study, 372 photographs were shot in manual mode within a 140-meter radius of PI in order to build the 3D geometric model of the monument, following Shervais (2015) and Smith et al. (2015) suggestions for the application of $\mathrm{SfM}$ in research. The data were collected with a NIKON D5300 reflex digital camera, 
with a 24.2 megapixel DX CMOS sensor and a fixed 35-mm focal length. The 3D reconstruction of the structure was completed by means of the Visual SFM open code software (Wu, 2007; 2011; 2013; Wu et al., 2011) and the images sequence. The scaling and georeferencing of the point cloud were carried out by implementing the 15 Ground Control Points (GCPs). The GCPs were materialized on a $1.5 \times 1.5 \mathrm{~m}$ piece of fabric bearing a red cross-shaped inscription, and their coordinates were determined by means of three Trimble 5700 receptors and differential GPS post processing (DGPS-L1) with CORS-INCA using RTKLB software (Takasu, 2009).

Scaling, georeferencing, point cloud editing, and mesh reconstruction by means of the Poisson algorithm (Kazhdan et al., 2006) were performed by means of the Meshlab open code software, which was developed at the Visual Computing Lab (Cignoni et $a l ., 2008)$. The $3 \mathrm{D}$ reconstruction obtained was used to generate a solid element of the geometry of PI by means of CAD software.

\subsection{Estimation of natural frequencies by ambient vibration test}

The process of developing a FEM of a structure involves assumptions and simplifications that may lead to error. These errors can usually be attributed to the inaccuracy in FEM discretization, to uncertainty in geometry and boundary conditions, and to variations in the properties of the material (Ribeiro et al. 2012). Therefore, the experimental tests can be compared to the results calculated through FEM, and the input parameters can be adjusted in this process in order to optimize the results and the precision of the model (Parloo, 2003). In some studies, such as the ones carried out by Ren and Peng (2005), Ariza (2012), Sequera Gutiérrez and Solano Rodríguez (2013), and Zong et al. (2015), among others, natural frequencies were used for FEM validation.

Following this methodology, the natural frequencies of the structure were estimated by an AVT based on an Operational Modal Analysis (OMA) method, where the excitation is originated by environmental or natural forces (wind, traffic, etc.) (Magalhães, 2012). OMA was found to be the most adequate method for extracting modal parameters in PI, as it is practical, affordable and non-invasive. It should be highlighted that due to its popularity and relative ease of implementation and application, the Peak-Picking (PP) modal identification method was used (Felber, 1993). Two GÜRALP CMG-40T triaxial broadband (0.02-50 Hz) and highsensitivity $(400 \mathrm{~V} / \mathrm{m} / \mathrm{s})$ seismometers and a GPS sensor (Fig. $3 \mathrm{~b})$ were used to perform the AVT. In addition, a system composed of two portable computers and a power supply system with an external battery, a solar panel, and a DC/AC converter were designed and implemented to acquire and store the seismometer data. Considering the recommendations for the configuration of the two sensors (the reference and rover sensors) in the Peak-Picking (PP) modal identification method (Felber, 1993), the test was performed following 15 measurement series on 16 sites (points: a, b, c, $\mathrm{d}, \mathrm{e}, \mathrm{f}, \mathrm{g}, \mathrm{h}, \mathrm{I}, \mathrm{j}, \mathrm{k}, \mathrm{l}, \mathrm{m}, \mathrm{o}, \mathrm{p}, \mathrm{q}$ ) on the bridge (see Fig. 3b). Point k was taken as a reference. The duration of each measurement was 12 minutes, bearing in mind that the recommended time for measuring should be 1000 and 2000 times longer than the highest expected natural frequency period (Rodrigues et al. 2004). 
In order to identify the natural frequencies, a piece of software was developed based on the identification method in the PP frequency domain (Felber, 1993) by the Random Decrement (RD) technique (Cole, 1968; 1973) using the Matlab software. The software enables the synchronization and cutting of the registers, the removal of tendency lines, the application of filters, the calculation of the Power Spectral Density (PSD) by means of the PSD-Welch (Welch, 1967) and PSD-RD methods, and the estimation of the Normalized Power Spectral Density (NPSD), Averaged Normalized Power Spectral Density (ANPSD) and Spectral Coherence Function (SCF). The peaks registered in the calculated ANPSD allow for the identification of natural frequencies. In order to avoid measuring in a node of the structure's mode shape, and to minimize the noise for the identification of natural frequencies through Spectral Coherence Function calculation, the measurement was carried out in 16 sites with two simultaneous sensors (reference and rover). The reference and rover sensors were synchronized by means of GPS clocks that were integrated into the seismometers.

\subsection{Puente del Inca's structural numerical model by FEM}

The Finite Element Method (FEM), widely used nowadays in the scientific and engineering community to solve structural, fluid, and multiphysic problems numerically (Bathe, 2008), was used to develop the computer structural model of PI. The software used to implement FEM and the validation process was the ANSYS Student simulation platform. It offers solutions for engineering problems such as static and dynamic structural analysis, heat transfer, and fluid, acoustic and electromagnetic mechanics (Chen and Liu, 2014).

As shown in the flowchart in Figure 2c, the model designed is divided into six processes and information flows associated with the input variables, the reference signal, the numerical model, validation, simulation and results. It should be highlighted that tetrahedral parabolic elements were used for the meshing process, since they offer better results than lineal elements when applied to structures that undergo flection states, such as beam bridges. Besides, as specified by Pérez González (2010), these elements model more efficiently curve surfaces, as it is the case with most of the geometry of PI. The input variables involve the mechanical characterization of the material and geometry (sections 3.3.1 and 3.3.2), and the boundary conditions. In order to define the boundary conditions, it was assumed that the abutments of the bridge were fixed. In relation to these variables, an estimation of the natural frequencies was simulated by means of the FEM model. These frequencies were compared to the reference signal in an iterative validation process. This process is intended to reduce the errors between the first 8 natural frequencies estimated by the numerical model and the natural frequencies obtained in Section 3.4 as a result of the adjustment of the input variables. Following this procedure, the Mean Percentage Error for the 8 Natural Frequencies (MPE8NF) was calculated for different input variables based on:

a) The boundary conditions reducing MPE8NF

b) A homogeneous bridge modeled on the basis of the mechanical parameters estimated for each of the 13 samples under dry and saturation conditions in Section 3.3.1. 
c) A bridge formed by three constituent layers of unknown thickness and with mechanical parameter values corresponding to those of the samples from the surface, medium, and bottom layers respectively (see Section 3.3.1). It should be noted that the fourth layer, corresponding to the stalactites growing from the intrados of the arch, has not been included in the model for simplification purposes, as it contributes little from the structural point of view. Given the complexity of this process, the thickness of the layers and the error-reducing parameters were determined by means of the Multi-Objective Genetic Algorithm (MOGA) optimization tool included in ANSYS (Lee, 2015). This algorithm was chosen because it effectively offers outstanding solutions for multi-objective problems set out in different engineering applications, as stated by Konak et al. (2006).

\subsubsection{Simulations}

Simulations were performed on the configuration produced by the minimum MPE8NF to study the structural behavior of the bridge. These simulations involved modal analysis (natural frequency and mode shape), static analysis (deformation and stress) and Safety Factor (SF) analysis based on the Mohr-Coulomb Failure Criterion (see Lawrence, 2012 and Goyal, 2012). SF is a magnitude that establishes how far apart tension relations are from the unitary value. Values that are lower than the unit represent points that have not passed the failure criterion and are prone to breaking. On the contrary, failures or cracks in the material will not occur when the SF values are equal or greater than the unit. Thus, this parameter allows one to determine the stability of the bridge and to identify the most vulnerable sectors in the structure.

\section{Results}

\subsection{Visual inspection and hydrothermal flow characterization}

The results obtained from VI successfully identified pathologies present in the structure of the bridge. These include: haunch and abutment deterioration, deterioration in the middle section of the arch, cracking and dryness of the roof, stalactites breaking off the intrados, erosion of the northeast haunch, erosion of the southern edge of the Cuevas river close to the western abutment, abutment subsidence, superficial deformation, lack of stability in the baths, differential subsidence of the baths, inferior bath collapse, ground level lifts in the vault, enlargement of the drainage deposits of the baths and ground level elevation in the baths. The main pathology in the natural bridge is caused by the breaking off and crumbling off of material from the intrados, haunch and abutment of the structure. These arch opening and regression processes, which from the onset gave PI its peculiar arch shape, currently continue to have an impact on the morphology of the structure. The detachment of material can be attributed to (eolic/fluvial/water) erosion, meteorization processes and seismic factors. Figure $4 \mathrm{a}$, b present two photographs: one of PI early in the $20^{\text {th }}$ century, and one taken today, where the thinning and loss of mass experienced by the bridge in the course of a century become evident. This is due mainly to the above mentioned processes. A white colored dotted ellipse signals the main detachments of material experienced by the northeast haunch area. In addition, Figure 4c, d shows examples of material detachment occurring in the abutment of the bridge. 

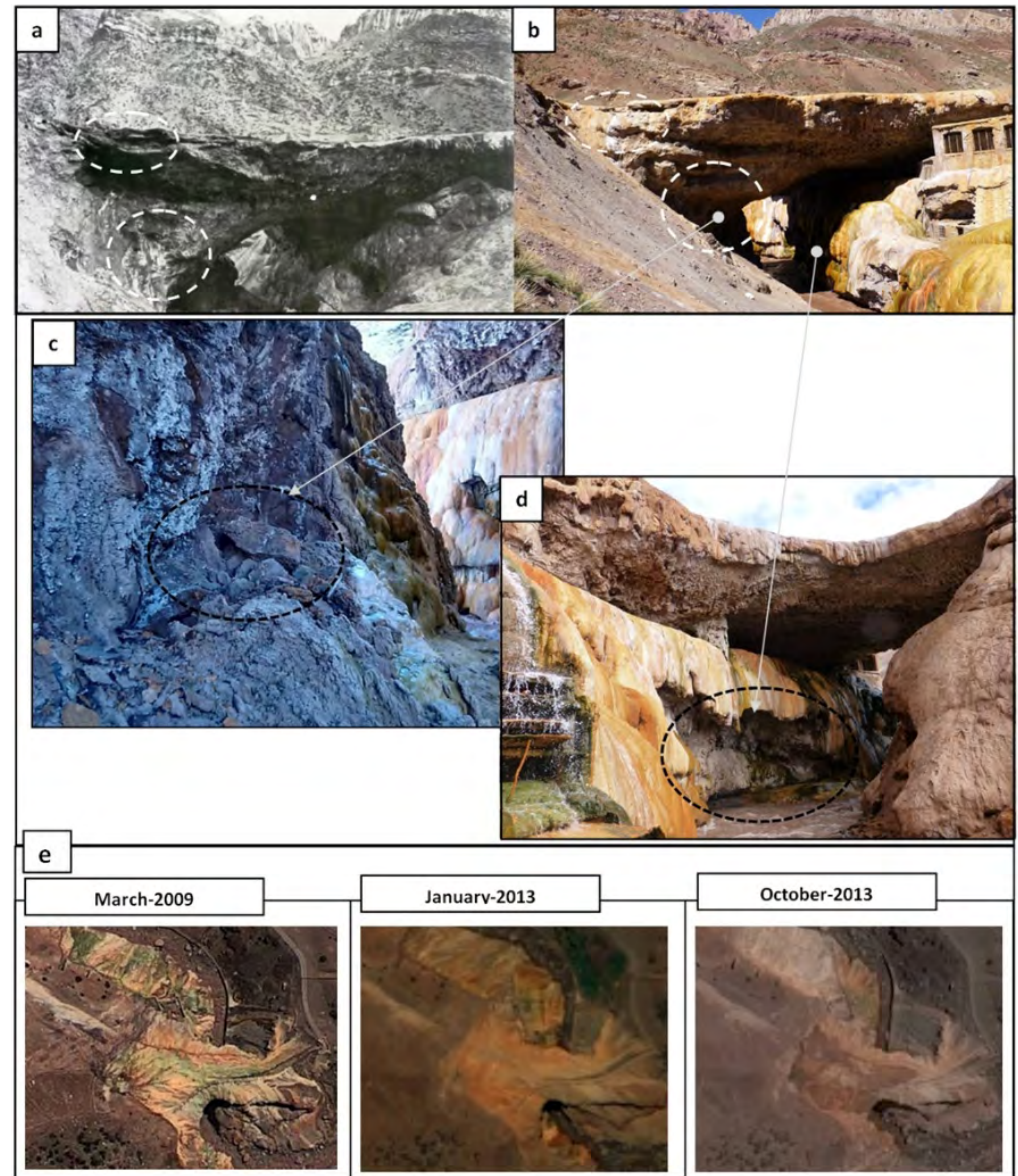

Figure 4. Breaking off and crumbling off of bridge structure material a) photograph of Puente del Inca at the beginning of the $20^{\text {th }}$ century (General Archives of the Province of Mendoza) and $b$ ) present day photography. The white dotted ellipse indicates the areas where most breaking off and crumbling off have been observed. c) Natural breaking off and crumbling off of material produced in the eastern abutment of the bridge in October 2016 (photo credit: Ricardo Abraham, Ranger, Puente del Inca Station). d) Breaking off and crumbling off of material produced in the western abutment of the bridge by the fluvial action of the Cuevas River. e) Discoloring and drying of the bridge in relation with the decrease and discontinuity of the thermal water flow in Fuente Copa de Champagne.

Another serious pathology involves the cracking and drying off of the cover of the natural structure. Figure 4e presents three satellite images of PI taken in March 2009, January 2013 and October 2013 where three clearly differentiated states of the cover can be appreciated. In March 2009, the thermal sources remained in a continuous state of activity and the geobiological processes kept a favorable interaction with the bridge. A gradual deterioration affecting the aspect and distinctive color of the cover can be clearly perceived in subsequent periods. This condition is marked by the irruption or discontinuity of the thermal water 
flow from Fuente Copa de Champagne, which leads to decoloration and drying off of the highest surface layer of the geoform. It should be highlighted that this pathology represents an instance of structural deterioration, but mostly leads to a devaluation of the landscape.

Hydrothermal Flow Characterization and accretion rate measurements become particularly important for the evaluation and control of these pathologies, as material detachment, thickness loss rates, and the drying off of the surface of the structure. These processes can be mitigated by the deposition of travertine by the thermal waters. A series of qualitative indicators based on data records, eye inspections and on-site surveys was generated to characterize the hydrothermal flows. These indicators are a relative qualitative weighting between hydrothermal flows related to landscape value, structural incidence, geothermal activity, qualitative discharge, facies, microbial communities and discharge / area relation. Table 2 shows the qualitative and quantitative results of the characterization and the average accretion-erosion rate of the four hydrothermal flows that are part of the geothermal environment of PI. These results reveal the importance of FCC, since it has the largest coverage range and a high structural and landscape incidence with discontinued geothermal activity and low accretion rates. However, the flows springing from the baths present, in general, opposing characteristics, which shows that the current irrigate of thermal water is inefficient. Lannutti (2017) offers a detailed description of the Hydrothermal Flow Characterization carried out in PI.

Table 2. Summary of the results of the Hydrothermal Flow Characterization and the average accretion-erosion rate estimation (2014-2016).

\begin{tabular}{|c|c|c|c|c|}
\hline & FCC & BDE & BDS & THB \\
\hline $\operatorname{Area}\left[\mathrm{m}^{2}\right]$ & 5453 & 623 & 1079 & 1155 \\
\hline Landscape value & High & High & High & High \\
\hline Structural Incidence & High & Medium & Medium & Low \\
\hline Geothermal Activity & Very discontinuous & Very frequent & Very frequent & Discontinuous \\
\hline Qualitative Discharge & Low & High & High & Medium \\
\hline $\begin{array}{c}\text { Facies } \\
\text { (see Fig. 1) }\end{array}$ & $4 \mid \begin{array}{l}\text {-Hot Spring } \\
\text {-Pit } \\
\text {-Channels } \\
\text {-Micro terraces }\end{array}$ & \begin{tabular}{|l|l}
4 & $\begin{array}{l}\text {-Bathing pools } \\
\text {-Channels and } \\
\text { ponds }\end{array}$ \\
-Drainage \\
-Micro terraces
\end{tabular} & \begin{tabular}{|c|l|}
5 & $\begin{array}{l}\text {-Bathing pools } \\
\text {-Channels }\end{array}$ \\
-Ponds \\
& -Terraces \\
& -Micro terraces \\
\end{tabular} & \begin{tabular}{|l|l}
3 & $\begin{array}{l}\text {-Hot Spring } \\
\text {-Channels } \\
\text {-Micro terraces }\end{array}$
\end{tabular} \\
\hline Microbial Communities & Low & $\begin{array}{l}\text { Medium high with clear } \\
\text { and dark hues }\end{array}$ & $\begin{array}{l}\text { High with dark } \\
\text { hues }\end{array}$ & $\begin{array}{l}\text { Low with clear } \\
\text { hues }\end{array}$ \\
\hline Discharge/Area Relation & Very low & Very high & High & Low \\
\hline $\begin{array}{l}\text { Average Accretion/Erosion } \\
\text { Rate (2014-2016) }\end{array}$ & $\begin{array}{c}\text { (P8-P9-P14-P15) } \\
0.38 \mathrm{~mm} / \mathrm{M}^{*}\end{array}$ & $\begin{array}{l}\text { (P6-P7-P12) } \\
8.49 \mathrm{~mm} / \mathrm{M}^{*}\end{array}$ & $\begin{array}{l}\text { (P1-P2-P3-P5- } \\
\text { P10-P11) } \\
19.75 \mathrm{~mm} / \mathrm{M}^{*}\end{array}$ & $\begin{array}{c}(\mathrm{P} 4-\mathrm{P} 13) \\
(\mathrm{n} / \mathrm{d}) * *\end{array}$ \\
\hline
\end{tabular}

*mm per month **no data available. The bars were lost during the measurement period

\subsection{Internal structure and surface displacements: GPR-SDS and GNSS}

GPR measurements helped to detect changes in internal structure such as heterogeneity, cavities and insets (Fig. 5a). Nevertheless, the primary control of the electromagnetic signal in the geothermal environment of PI is driven by the thermal 
water from FCC. This condition masks the detection of changes in the properties of the materials constituting the structure (see Lannutti et al., 2017). In this sense, GPR did not provide information that could contribute to the development of a more precise structural numerical model. However, it was possible to determine the homogeneous distribution and the important role of thermal water within the structure when FCC is active (see Fig. $5 b)$. This information is relevant to the protection and recovery measures of PI, bearing in mind the close relationship between thermal water and the integrity of the natural bridge.

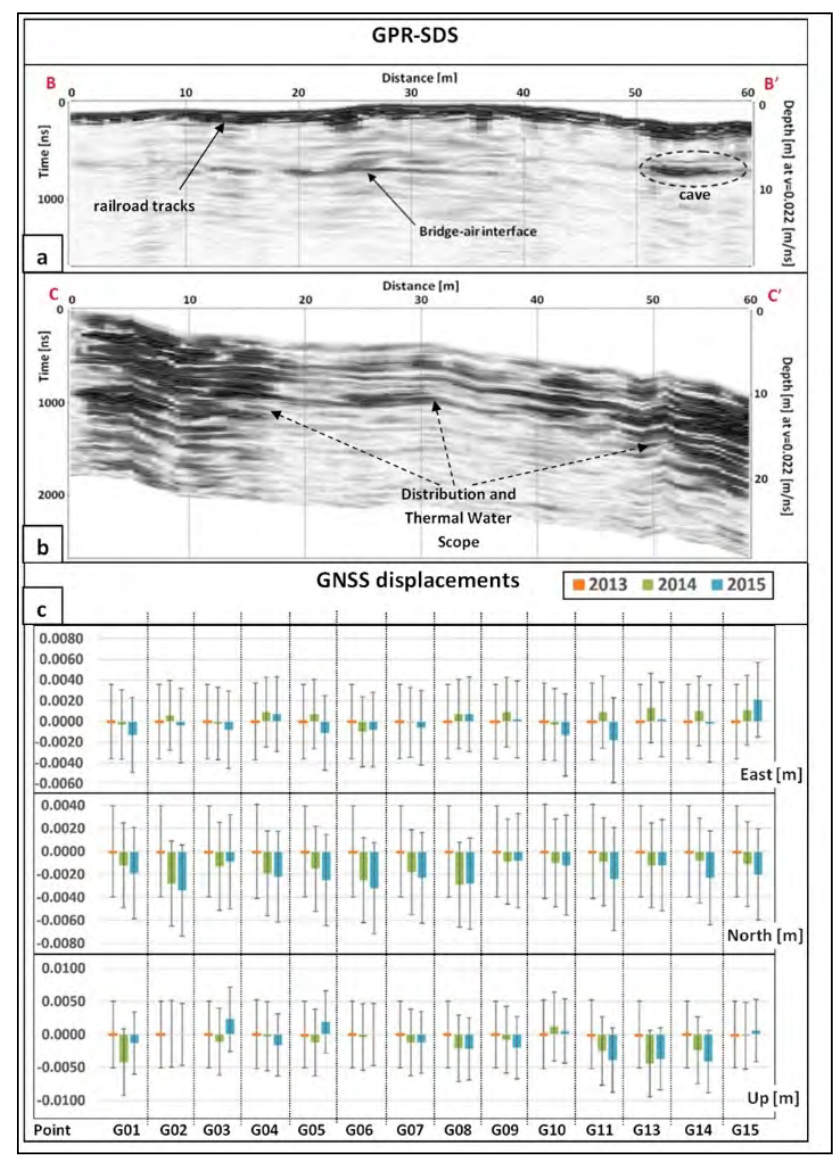

Figure 5. GPR-SDS and GNSS: a) B-B' longitudinal profile on the bridge's northern edge with 20-Mhz measurements. The cavity can be observed in the final part of the profile, indicated with a dotted-line ellipse, and possible remains of railroad tracks following the edge and the upper part of the bridge. b) C-C'longitudinal profile on the southern edge with 20-Mhz measurements. The abutments and the arch of the bridge can be observed, as well as the distribution of moisture content from the hot springs in the area. c) East, north and up displacements, and error in the coordinates of the fourteen points installed on the natural structure during the 2013-2013, 20132014 and 2013-2015 periods. 
Figure 5c shows the east, north and up displacements of the 14 GPS points on the structure (G01-G02-G03-G04-G05-G06-G07-G08-G09-G10-G11-G13-G14-G15), for the 2013-2014-2015 periods, with 2013 as a reference. It also shows the error incurred in the estimation of the coordinates. In view of the errors, the proposed methodology and architecture for the DGPS auscultation (number of points, location, kind of monumentation, receptors and antennas, measurement time, software and processing strategies, etc.) proved feasible and efficient, as millimetric precisions can be achieved. However, as shown in the flowcharts, none of the displacements is out of the range of the measurement error. These results suggest that the GPS points do not undergo displacements greater than those this methodology can detect. In brief, in three years, the natural structure and the baths have not undergone surface displacements greater than $0.0036 \mathrm{~m}$ (east), $0.0039 \mathrm{~m}$ (north), and $0.0050 \mathrm{~m}$ (up) in the implemented points. Thus we believe it is necessary to extend and increase the number of measurements to improve the temporal series and be able to observe greater displacements in a longer time series, so that they may be out of the error area.

\subsection{Mechanical parameters of the material and 3D geometry of the structure: $L T$ and $S f M$}

Table 3 presents a summary of the mechanical characterization of the travertine with the values of the input parameters proposed for the structural model of PI divided into dry and saturated material. From these results, the four hypothesized layers were identified: surface, medium, bottom and stalactite (see Fig. 3c), as characterized by the density of the material (@), elasticity modulus (E), Poisson's ratio $(v)$, and compressive and tensile strength $(\sigma c, \sigma t)$ values. In relative terms, the samples taken from the surface layer present low values of compression and traction resistance ( $\sigma \mathrm{c}$ and $\sigma \mathrm{t})$ and low to medium elasticity (Ed) and apparent density (Q). Instead, those taken from the medium present high values for the same four parameters. As for the cores taken from the bottom and the stalactite, they present medium relative $\sigma c, \sigma t, E d$ and $\varrho$ values, with the exception of stalactites, which present low $\sigma \mathrm{c}$. If we compare the results for dry and water saturated samples, on average, $\varrho$ increased by $10.4 \%$, $\sigma \mathrm{c}$ and $\sigma \mathrm{t}$ decreased by $37.2 \%$ and $24.8 \%$, respectively, and Ed increased by $4.4 \%$. It is important to emphasize that these four layers were also identified qualitatively based on the different morphological aspects displayed by the materials. Figure 6 presents a summary of the results obtained taking into account the qualitative and quantitative characteristics identified in each of the four layers (Lannutti, 2017). 
Table 3. Summary of the results of the mechanical parameters of the extracted samples.

\begin{tabular}{|c|c|c|c|c|c|c|c|c|c|}
\hline Layers & Sample & $\underset{[\mathrm{kg} / \mathrm{m} 3]}{\stackrel{\varrho}{2}}$ & $\begin{array}{c}\mathbf{E d} \\
{[\mathbf{G P a}]}\end{array}$ & $v$ & $\begin{array}{c}\text { бc/ot } \\
{[\text { Mpa }]}\end{array}$ & $\begin{array}{c}\text { osat* } \\
{[\mathrm{kg} / \mathrm{m} 3]}\end{array}$ & $\begin{array}{l}\text { Edsat* } \\
\text { [GPa] }\end{array}$ & $v$ sat* & $\begin{array}{c}\sigma c / \sigma t \\
\text { sat* [Mpa }]\end{array}$ \\
\hline Stalactite & $5 \mathrm{~A}$ & 1553 & 13.06 & 0.33 & $2.03 / 0.63$ & 1716 & 13.55 & 0.33 & $1.28 / 0.47$ \\
\hline Surface & $1 \mathrm{~A}$ & 320 & 1.57 & 0.33 & $3.31 / 0.84$ & 372 & 1.60 & 0.33 & $2.09 / 0.64$ \\
\hline Surface & $4 \mathrm{~A}$ & 1737 & 9.30 & 0.33 & $2.72 / 0.75$ & 2020 & 9.49 & 0.33 & $1.50 / 0.52$ \\
\hline Surface & $8 \mathrm{~B}$ & 1078 & 6.91 & 0.32 & $4.25 / 0.98$ & 1254 & 7.05 & 0.33 & $2.68 / 0.74$ \\
\hline Surface & $9 \mathrm{~A}$ & 1388 & 9.94 & 0.32 & $4.15 / 0.97$ & 1614 & 10.14 & 0.33 & $2.90 / 0.78$ \\
\hline Surface & $8 \mathrm{~A}$ & 1580 & 13.56 & 0.33 & $3.34 / 0.85$ & 1838 & 13.83 & 0.33 & $2.11 / 0.64$ \\
\hline Bottom & $6 \mathrm{~A}$ & 1207 & 10.17 & 0.32 & $5.72 / 1.18$ & 1279 & 10.56 & 0.33 & $3.60 / 0.89$ \\
\hline Bottom & $6 \mathrm{~B}$ & 1556 & 13.11 & 0.32 & $8.67 / 1.52$ & 1649 & 13.61 & 0.32 & $5.45 / 1.14$ \\
\hline Medium & $7 \mathrm{~A}$ & 1687 & 15.90 & 0.32 & $6.59 / 1.28$ & 1793 & 17.05 & 0.32 & $4.13 / 0.96$ \\
\hline Medium & 7B & 1831 & 20.46 & 0.32 & $9.07 / 1.56$ & 1946 & 21.93 & 0.32 & $5.68 / 1.17$ \\
\hline Medium & $3 \mathrm{~B}$ & 2080 & 24.49 & 0.32 & $10.07 / 1.66$ & 2211 & 26.25 & 0.32 & $6.30 / 1.25$ \\
\hline Medium & $3 \mathrm{~A}$ & 1917 & 25.30 & 0.30 & $22.2 / 2.69$ & 2038 & 27.12 & 0.31 & $13.90 / 2.02$ \\
\hline Medium & $2 \mathrm{~A}$ & 1961 & 30.49 & 0.31 & $16.41 / 2.24$ & 2085 & 32.69 & 0.32 & $10.27 / 1.68$ \\
\hline
\end{tabular}

$\rho=$ density; $\mathrm{Ed}=$ dynamic elasticity modulus; $v=$ Poisson's ratio; $\sigma \mathrm{c}=$ compressive strengths; $\sigma \mathrm{t}=$ tensile strengths

*sat=saturated samples.

\begin{tabular}{|c|c|c|c|c|c|c|c|}
\hline \multicolumn{2}{|c|}{$\begin{array}{l}\text { Layers } \\
\text { core }\end{array}$} & Sketch & Photograph & $\sigma c$ & Ed & $\rho$ & Description \\
\hline 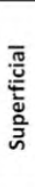 & $\begin{array}{l}1 \mathrm{~A} \\
4 \mathrm{~A} \\
8 \mathrm{~A} \\
8 \mathrm{~B} \\
9 \mathrm{~A}\end{array}$ & & & בై & 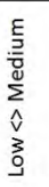 & 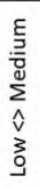 & $\begin{array}{c}\text { Superficial } \\
\text { travertine } \\
\text { deposits formed } \\
\text { by geobiological } \\
\text { processes }\end{array}$ \\
\hline 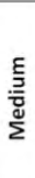 & $\begin{array}{l}2 A \\
3 A \\
3 B \\
7 A \\
7 B\end{array}$ & & & 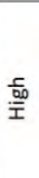 & 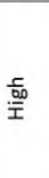 & $\begin{array}{l}\frac{c}{00} \\
\frac{.00}{1}\end{array}$ & $\begin{array}{c}\text { Inner travertine } \\
\text { deposits densified } \\
\text { by physical and } \\
\text { chemical } \\
\text { processes }\end{array}$ \\
\hline E & $\begin{array}{l}6 \mathrm{~A} \\
6 \mathrm{~B}\end{array}$ & & & $\frac{\varepsilon}{\frac{E}{3}}$ & $\frac{E}{\frac{E}{3}}$ & $\frac{E}{\underline{\Xi}}$ & $\begin{array}{l}\text { Detritus } \\
\text { cemented by } \\
\text { thermal water }\end{array}$ \\
\hline 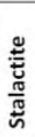 & $5 A$ & & & ơ & $\frac{E}{\stackrel{E}{z}}$ & 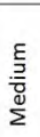 & $\begin{array}{l}\text { Stalactites } \\
\text { formation }\end{array}$ \\
\hline
\end{tabular}

Figure 6. Summary of the characteristics found in the samples taken from the surface, middle, bottom and stalactite layers, where the cores, sketches, photos example, comparative values of density $(\rho)$, elasticity modulus $(E d)$, compressive strength $(\sigma c)$ and description of each layer are specified. 
On the other hand, a 3D reconstruction of the bridge was obtained from SfM, with a precision of $0.08 \pm 0.04 \mathrm{~m}$, an average resolution of 150 points per square meter, a covered extension of 20,000 square meters, and an acquisition velocity of $1,850,000$ points per hour with low operating costs. These features show that this technique efficiently generated the 3D model geometry to be used as an input parameter for the PISNM. The image in Figure 7a shows the superposition of dense points obtained by SfM and the reconstruction of the surface obtained by means of Poisson's algorithm (Fig.7b). Figure $7 \mathrm{c}$ shows the solid element of the PI geometry edited by CAD software.

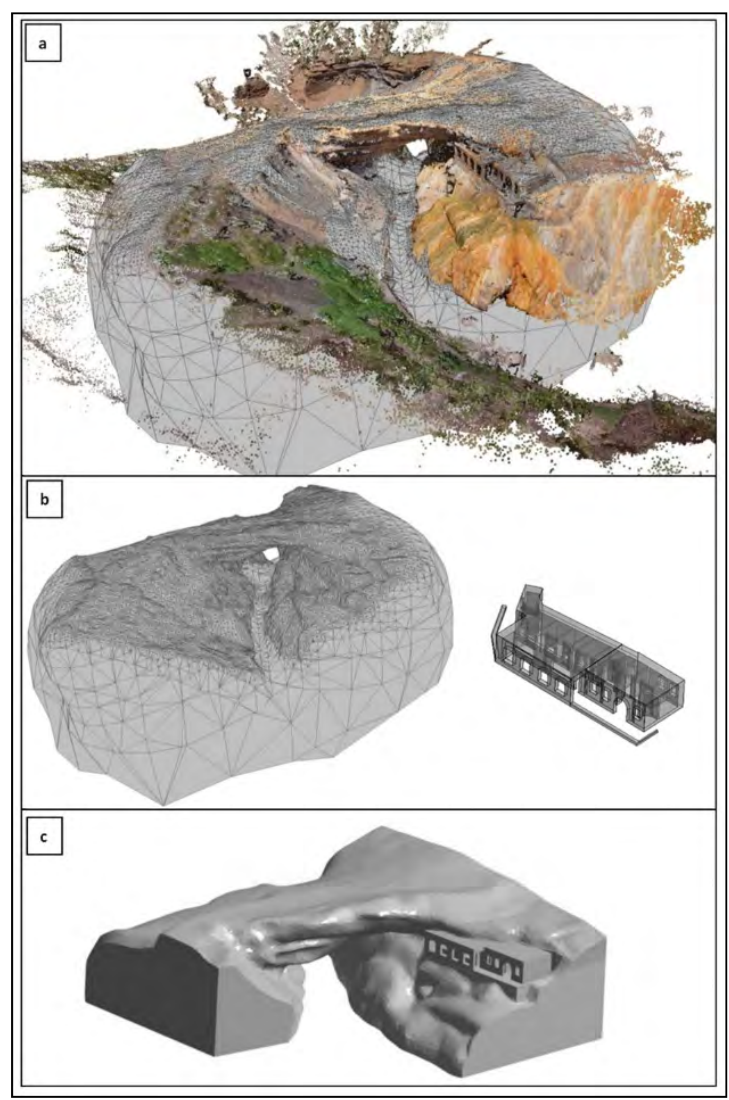

Figure 7. SfM: a) Point cloud produced using the SfM technique and $3 D$ reconstruction of the structure. b) $3 D$ reconstruction obtained and $3 D$ design of the thermal baths. $c$ ) solid element of the geometry of PI designed by means of CAD software.

\subsection{Ambient vibration test}

Figure 8a shows the ANPSD, as calculated by the PSD-Welch and PSD-RD method. In the first case, five peaks $(24.8,27.7,30.1,37.2$ and $39.3 \mathrm{~Hz})$ were identified corresponding to 
the natural frequencies; however, in the second case, eight peaks $(17.55,24.75,27.65,30.12$, $33.26,37.22,39.25$ and $43.2 \mathrm{~Hz}$ ) were identified, corresponding to the first eight vibration modes. The comparison of the results obtained by both methods clearly reveals the noise reduction in the RD method. These results coincide with those obtained by Rodrigues et al. (2004), where the same two techniques were compared. The frequencies corresponding to the first, fifth and eight modes do not appear in PSD-Welch, as this method does not efficiently eliminate noise, as RD functions do. On the other hand, both graphs show a break as of 44 $\mathrm{Hz}$, although it cannot be claimed that this peak should correspond to a natural frequency, as it may be related to the broadband limit of the seismometers.

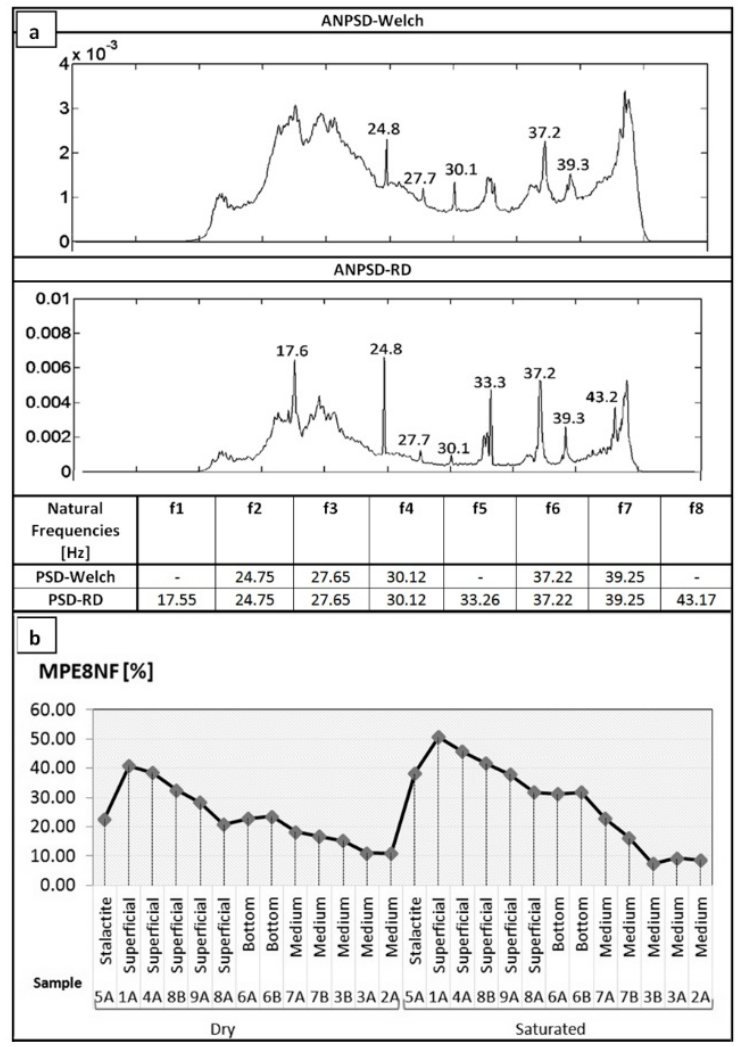

Figure 8. a) Natural frequencies determined from AVT and the PP identification method for the Averaged Normalized Power Spectral Density-Welch and RD. b) Mean Percentage Error for the 8 Natural Frequencies (MPE8NF) calculated from the homogeneous FEM model for the 13 samples in dry and water-saturated conditions.

\subsection{Puente del Inca Structural Numeric Model}

Figure $8 \mathrm{~b}$ shows the Mean Percentage Error for the 8 Natural Frequencies (MPE8NF) calculated for a homogeneous bridge (unlayered model). The minor errors 
correspond to samples taken from the middle section of the bridge, especially when the samples were under saturation conditions. The minimum error achieved was of $4.3 \%$ for the 2A saturated sample. This condition reveals that the bridge is mainly composed of material with the mechanical characteristics described in the samples taken from the middle section of the bridge under saturation conditions.

In the case of the three layer model, the error exposed by the MOGA method for the optimum candidate is $2.6 \%$. The parameters and thickness of the layers for this case are shown in Table 4. The simulation of the structural response of the bridge was performed taking this condition as the most representative model. Figure 9 shows the simulation of the modal analysis, where natural frequency and mode shape are detailed for the first eight structural vibration modes. Note that the structure of PI presents an irregular and asymmetrical morphology. However, after the simulation, it can be seen that it presents the vertical, torsional and lateral vibration modes that are generally present in civil infrastructure (such as bridge). The $\mathrm{f} 1, \mathrm{f} 4$ and $\mathrm{f} 8$ frequencies $(17.5 \mathrm{~Hz}, 29.9 \mathrm{~Hz}$ and $43.0 \mathrm{~Hz}$ ) present vertical deformations and thus correspond to the vertical vibration modes of the structure. In the case of the $\mathrm{f} 2$ and $\mathrm{f} 6$ frequencies $(23.4 \mathrm{~Hz}$ and $35.7 \mathrm{~Hz})$, the deformations are lateral; while for f3, f5 and $\mathrm{f} 7$ (27.1, 34.5 and $40.6 \mathrm{~Hz}$ ) they are torsional and related to the lateral and torsional modes, respectively.

Table 4. Candidates calculated by the MOGA method for the three-layer structural model.

Thickness of the surface and medium layers corresponding to distances d1 and d2 (see Fig. $3 \mathrm{c}$ ).

\begin{tabular}{|c|c|c|c|}
\hline Parameters & Surface & Medium & Bottom \\
\hline oS $\left[\mathbf{k g} / \mathbf{m}^{3}\right]$ & 549 & 1915 & 1410 \\
\hline EdS [GPa] & 10.03 & 31.74 & 13.04 \\
\hline $\mathbf{d}[\mathbf{m}]$ & $\mathrm{d} 1=0.45$ & $\mathrm{~d} 2=9.7$ & - \\
\hline ocs [Mpa] & 2.24 & 8.06 & 4.53 \\
\hline ots [Mpa] & 0.66 & 1.42 & 1.02 \\
\hline
\end{tabular}

$\rho=$ density; $\mathrm{Ed}=$ dynamic modulus of elasticity; $\sigma \mathrm{c}=$ compressive strengths and $\sigma \mathrm{t}=$ tensile strengths. ${ }^{*} \mathrm{~S}=$ waterwater saturation conditions.

Next, Figure 10 presents the static response of the structure under its own weight including the calculation of deformation, stress and Safety Factor (SF). As shown in Figure 10a, the greatest displacements, ranging between $0.001-0.0015 \mathrm{~m}$, can be observed on the northern edge. This is due to the north-south asymmetry of the geoform, where the northern side presents the greatest clear span and rise of the bridge. Great stresses can be observed on the main baths, particularly on the bath that is closest to the bridge, which reaches stresses of up to $4 \mathrm{MPa}$. This suggests that the baths are interacting with the structure of the bridge. The greatest stresses are clearly sectorized: they affect the sector of the east haunch-abutment, both on the north and south-center sides (0.5-2 MPa); mid-intrados (0.5-2.5 MPa); the break generated between the west intrados and abutment, which runs along the side of the vault, and the upper part of both abutments (1-2 MPa). 


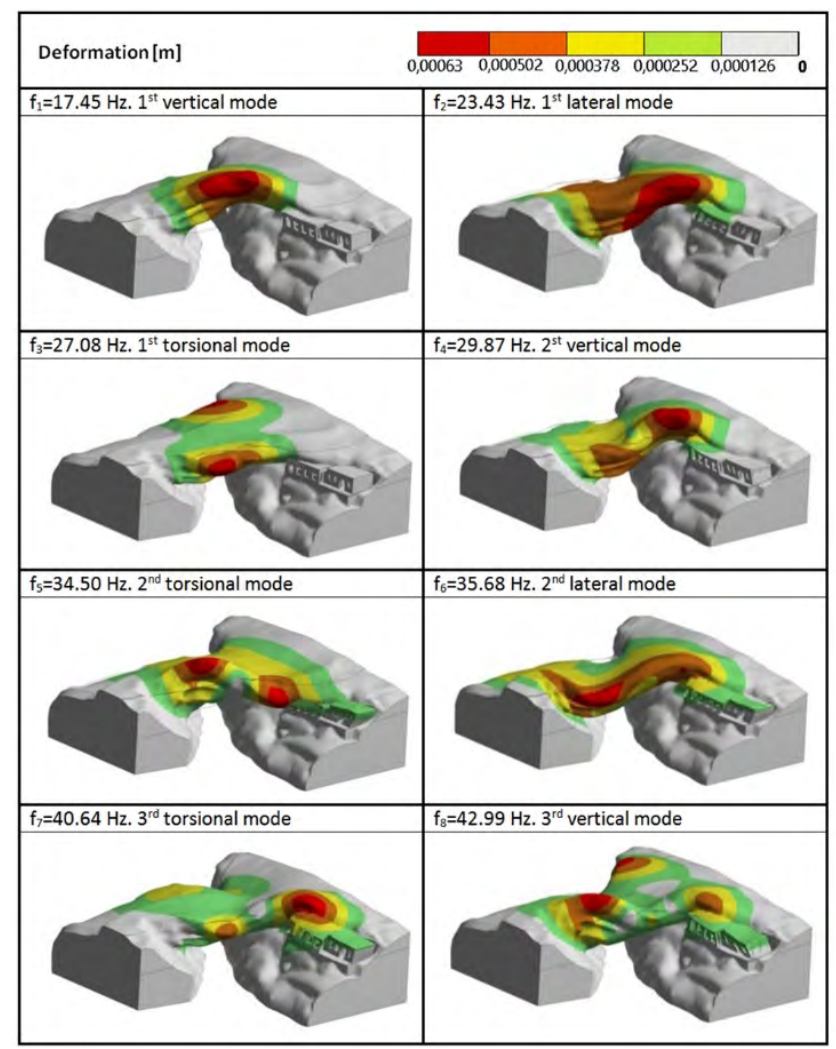

Figure 9. Mode shape and natural frequencies for the first eight vibration modes. Note the outstanding group of vertical, lateral and torsional modes in this figure.

Figure 10b displays the calculated SF for the model under saturation and dryness conditions. In both cases, none of the points of the structure reached FC values lower than the unit; therefore, the bridge is stable under its own weight. Nevertheless, there are areas with SF values close to the unit in the medium section of the bridge, mostly under saturation conditions, given the increase in the apparent density of the material caused by interstitial water and lower compressive and tensile strengths (see Table 3). This condition of increased density and loss of material strength is a fundamental finding since it questions the benefit of irrigating the structure for the structural health improvement. The most affected sector is the intrados in the medium part of the bridge, with an SF value of 1.5. Due to the fact that this sector works under flection, its upper part becomes compressed, and its lower part experiences traction strains. The low $\mathrm{SF}$ value found for this section is related to the rock forming the structure presents a resistance to traction ( $\sigma \mathrm{t})$ that is lower than the resistance to compression $(\sigma c)$ (See Table 3). Contrarily to this, the upper part presents higher SF values, as it works under compression. 


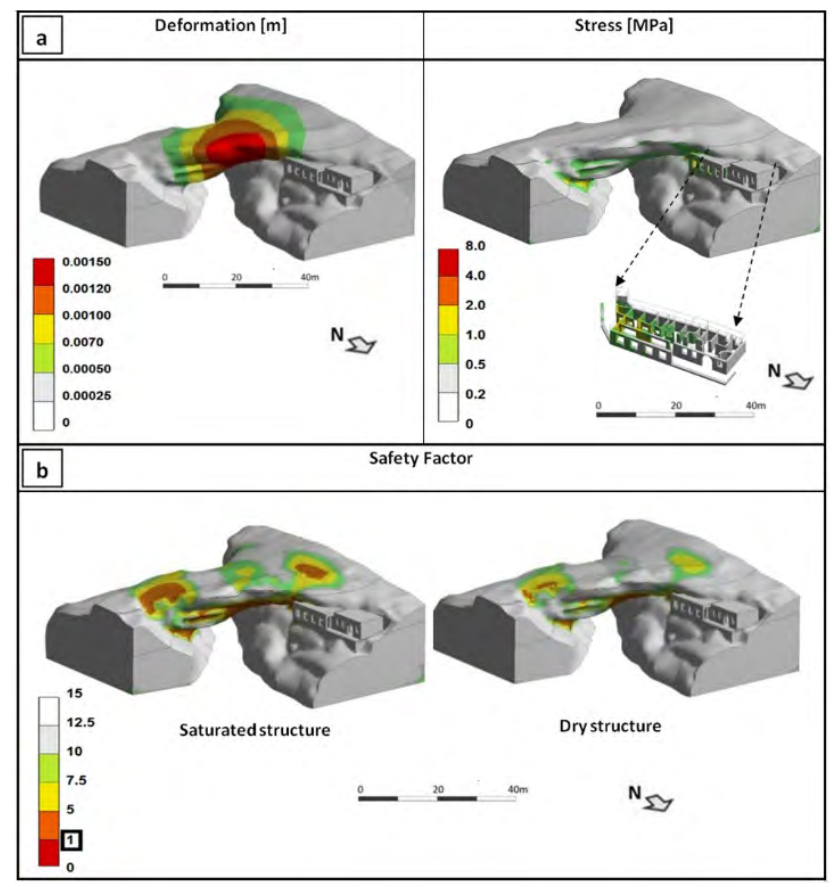

Figure 10. Estimated deformation, stress and safety factor from the load caused by the weight of the structure.

\section{PISNM discussion}

The design and implementation of PISNM was based on the MEF, which is at present extensively used in scientific and industrial contexts (Bathe 2008). Ample literature is available on MEF that outlines the range of applications involving structural models, solid mechanics, geotechnics, fluid mechanics, transportation problems, nonlinear problems, electromagnetism, and heat transfer, as those described by Potts and Zdravković (2001), Logan (2011), Larson and Bengzon (2013). Although no literature has been found where MEF has been applied to a travertine natural bridge, the potential and versatility of this method drove us to develop a structural model of Puente del Inca using this tool. The results reached highly satisfactory precision levels, mostly due to the processes of model validation.

As shown by the results in section 4.3, the tested samples indicate that the travertine material presents irregularities such as cracks, cavities, foliation, porosity, laminations, and micro-cracks. These conditions detract from the accuracy of the materials test results, particularly those which are indirect such as ultrasound tests, and thus from the final accuracy of PISNM. In the simulation of the static and free oscillation responses of the structure, which are not related to high speed loads, the static elasticity module may be used. However, the elasticity module used as an input 
parameter for PISNM corresponds to a dynamic module, as it was estimated by means of ultrasound tests. Martinez-Martinez et al. (2012) and Najibi et al. (2015) claim that the greater the discontinuities in the tested material, the greater the overestimation of the dynamic elastic parameters as compared with the static parameters. Higher elasticity module values could lead to an overestimation of the natural frequencies of the structure calculated by means of MEF. Yet, the agreement between the frequencies simulated in section 4.5 with respect to the ambient vibration test in section 4.4 supports the view that the elasticity module has not been overestimated, and so the dynamic and static elastic parameters must be similar. This is attribute to the structural response of the geoform is predominantly ruled by travertine material in the medium layer, which presents homogeneity, isotropy and continuity conditions. This determined the precision of the tests for these materials and ultimately the low $4.3 \%$ and $2.6 \%$ errors attained by the computational model. For the lowest error discrete model $(2.6 \%)$, the thicknesses of the surface $(0.45 \mathrm{~m})$, medium $(9.7 \mathrm{~m})$ and bottom (undefined) layers were defined by two distances obtained by means of the optimization process (MOGA method). These distances correspond to two discrete limits that may possibly be progressive transitions in reality, particularly the boundary between the surface and medium layers. It is possible for the medium travertine to contain detrital material, while the bottom may contain travertine material. Nevertheless, in the case of the boundary between the medium and bottom layers, the $9.7 \mathrm{~m}$ thickness estimated for the model coincides exactly with a marked 10-m thick transition that may be observed along the structure and which corresponds with the deck of the bridge (See the white arrow on Fig. 1). Thus, this approximation is valid, as this transition matches the base material proposed in the formation hypothesis by Darwin (1838), Kittle (1941), Monteverde (1946), Aguirre Urreta and Ramos (1996) and Fauqué et al. (2009).

\section{Conclusions}

The methodology used for the study of Puente del Inca, based on the integration of the proposed methods and techniques, provided satisfactory answers to the stated objectives and efficient numerical solutions for the evaluation of the natural structure. Puente del Inca is a geobiological system formed by hot springs flowing in the area. The landscape and structural integrity of the geological formation is undergoing a regression process due to natural and anthropic factors that cause erosive processes to be more intense than the travertine cementation and deposition processes. The structure is stable under its own weight; however, it presents some points where the Safety Factor is close to the unit, especially under saturation conditions. These points correspond to areas where there has been greater rockfall.

When hot springs flow continuously, high accretion rates are obtained, which is suggestive of a fast travertine deposition. Nevertheless, the structural numeric model demonstrates that there is a controversy between the benefit of irrigating the geological formation with thermal water and the loss of stability of the bridge under saturation conditions. In this sense, to contribute to the conservation of the Puente del Inca, it is proposed: (i) To compensate the hydrothermal flows through hydraulic structures to lead 
baths water, which are mostly lost to the river, towards the upper part of the bridge (FCC). In this way the FCC spring will not be subject to temporary discontinuities that may affect the structure integrity. (ii) To lead the water in a homogeneous way to the northeast-eastsoutheast directions from upper thermal water, in order to consolidate the abutment and prevent landslides. iii) To lead the water to the East abutment by waterproofing a channel over the bridge middle surface so that the water does not overload or weaken this arch sector that is the most structurally compromised.iv) To make constant monitoring of the bridge to record the health of the geobiological system and structure evolution.

\section{Acknowledgments}

The authors would like to thank Dirección de Recursos Naturales Renovables (Bureau of Renewable Resources) of the Province of Mendoza and their staff for their support, Puente del Inca Station Forest Ranger, as well as Alberto Rubio, Darío Trombotto, Estefanía Bottegal, Mario Gonzalez, Mario Rosas, Raúl Zaradnik, Richard Branham, Robert Smalley, Roberto Haroldo Bruce and Sebastián Crespo. We would also like to thank IANIGLA CONICET's Geomatics Department.

\section{References}

Aguirre Urreta, M.B., Ramos, V.A. 1996. Áreas de interés. In: V.F.A. Ramos (Ed.) Geología de la región del Aconcagua. Anales de la Dirección Nacional del Servicio Geológico, Subsecretaría de Minería 24 (15), Buenos Aires, pp. 471-480.

Ariza, G.F.2012. Calibración del modelo numérico existente de una edificación de valor histórico mediante mediciones de vibración ambiental. Caso de estudio: templo de San Francisco de Asís de Bucaramanga. Universidad Industrial de Santander-UIS. Bucaramanga, Santander, Colombia, pp. 12-100.

Bathe, K.J. 2008. Finite element method. John Wiley \& Sons.

Bayari, C.S. 2002. A rare landform: Yerköprü travertine bridges in the Taurids Karst Range, Turkey. Earth Surface Processes and Landforms 27 (6), 577-590. https://doi.org/10.1002/ esp.337.

Bayari, C.S., Kurttaş, T. 1997. Algae: An important agent in deposition of karstic travertines: Observations on natural-bridge Yerköprü Travertines, Aladağlar, Eastern Taurids, Turkey. Karst Waters \& Environmental Impacts, 269-279.

Biskup, K., Lorenzo, H., Arias, P. 2005. Aplicabilidad del radar de subsuelo para el estudio de la zona no saturada del suelo: ejemplos en ambientes arenosos costeros. In: VII Jornadas de Investigación en la Zona No Saturada del Suelo: ZNS'05. A Coruña, España. Servizo de Publicacións, pp. 197-204.

Carson, J.S. 2002. Model verification and validation. Simulation Conference. IEEE Proceedings of the Winter 1, pp. 52-58.

Cheng, P., John, W., Zheng, W. 2002. Large structure health dynamic monitoring using GPS technology. In FIG XXII International Congress, Washington, DC USA.

Chen X., Liu Y. 2014. Finite element modeling and simulation with ANSYS Workbench. CRC Press.

Cignoni, P., Callieri, M., Corsini, M., Dellepiane, M., Ganovelli, F., Ranzuglia, G. 2008. Meshlab: An open-source mesh processing tool. In: Eurographics Italian Chapter Conference, pp. 129-136. 
Cole, H.A. 1968. On-the-line analysis of random vibrations. AIAA Paper 68, 288 pp.

Cole, H.A. 1973. On-line failure detection and damping measurements of aerospace structures by random decrement signature. NASA CR-2205.

Cornejo, L. 2008. El sitio inka Puente de Tierra (Alto río Maipo, Chile) y la frontera sur del Tawantinsuyu. Revista Clava 7, 73-84.

Dach, R., Hugentobler, U., Fridez, P., Meindl, M. 2007. Bernese GPS software version 5.0. Astronomical Institute, University of Bern.

Darwin, C. 1838. Journal of researches into the natural history and geology of the countries visited during the voyage of the H.M.S. Beagle around the World. John Murray, London, 512 pp.

De-ren LI. 2007. On geomatics in multi-discipline integration [J]. Acta Geodaetica et Cartographica Sinica 4: 002.

Di Crescenzo, G., Santo, A. 2007. High-resolution mapping of rock fall instability through the integration of photogrammetric, geomorphological and engineering-geological surveys. Quaternary International 171, 118-130. https://doi.org/10.1016/j.quaint.2007.03.025.

Fauqué, L., Hermanns, R., Hewitt, K., Rosas, M., Wilson, C., Baumann, V., Lagorio, S., Di Tommaso, I. 2009. Mega-deslizamientos de la Pared Sur del Cerro Aconcagua y su relación con depósitos asignados a la glaciación Pleistocena. Revista de la Asociación Geológica Argentina 65 (4), 691-712.

Felber, A.J. 1993. Development of a hybrid bridge evaluation system. PhD Thesis, University of British Columbia, Vancouver.

Ferrari, S.G., Italiano, M.C, Silva, H.J. 2002. Effect of a cyanobacterial community on calcium carbonate precipitation in Puente del Inca (Mendoza, Argentina). Acta Botánica Croatica 61(1), 1-9. https://hrcak.srce.hr/3479.

Feth, J.H., Barnes, I. 1979. Spring-deposited travertine in eleven western states. U.S. Geological Survey Water Resources Investigation, Open file report, pp. 79-35.

Fouke, B.W. 2011. Hot-spring systems geobiology: Abiotic and biotic influences on travertine formation at Mammoth Hot Springs, Yellowstone National Park, USA. Sedimentology 58 (1), 170-219. https://doi.org/10.1111/j.1365-3091.2010.01209.x.

Galán-Martín, D., Martínez-Marín, R., Marchamalo-Sacristán, M., \& Sánchez-Sobrino, J. A. (2011). Control de movimientos en presas mediante DGPS: Aplicación a la presa de La Aceña, España. Tecnología y ciencias del agua 2 (3), 159-176.

Gandin, A., Capezzuoli, E. 2014. Travertine: Distinctive depositional fabrics of 584 carbonates from thermal spring systems. Sedimentology 61, 264-290. https://doi.org/10.1111/ sed.12087.

Goyal, V.K. 2012. Elements of machine design I. PhD Thesis, Department of Mechanical Engineering, University of Puerto Rico at Mayaguez, Mayaguez, Puerto Rico.

Hammer, Ø., Dysthe, D.K., Jamtveit, B. 2007. The dynamics of travertine dams. Earth and Planetary Science Letters 256 (1), 258-263. https://doi.org/10.1016/j.eps1.2007.01.033.

Howard, A.P. 1948. An unusual type of natural bridge. American Journal of Science 246, 593. https://doi:10.2475/ajs.246.9.593.

Kazhdan, M., Bolitho, M., Hoppe, H. 2006. Poisson surface reconstruction. Proceedings of the Fourth Eurographics symposium on Geometry processing 7, pp. 61-70.

Kittl, E. 1941. El Puente del Inca, su formación y conservación. Revista Minera 12 (3-4), 110-122, Buenos Aires.

Konak, A., Coit, D.W., Smith, A.E. 2006. Multi-objective optimization using genetic algorithms: A tutorial. Reliability Engineering \& System Safety 91 (9), 992-1007. https://doi.org/10.1016/j. ress.2005.11.018.

La Touche, T.D. 1906. Note on the Natural Bridge in the Gokteik Gorge. Record of the Geological Survey of India 33, 49-54. 
Lambot, S., Slob, E., Chavarro, D., Lubczynski, M., Vereecken, H. 2008. Measuring soil surface water content in irrigated areas of southern Tunisia using full-waveform inversion of proximal GPR data. Near Surface Geophysics 6 (6), 403-410. https://doi.org/10.3997/18730604.2008028.

Lannutti, E., Lenzano, M.G., Barón, J., Lenzano, L.E. 2017. Using ground-penetrating radar to investigate the internal structure of Puente del Inca, Mendoza, Argentina. Near Surface Geophysics 15 (2), 175-186. https://doi.org/10.3997/1873-0604.2017004.

Lannutti, E. 2017. Modelado numérico mediante la técnica de SHM (Structure Health Monitoring) aplicado a una estructura natural. Caso de estudio: Monumento Natural Puente del Inca. Tesis de Doctorado. Facultad de Ingeniería. Universidad Nacional de Cuyo. Argentina.

Larson, M.G., Bengzon, F. 2013. The finite element method: Theory, implementation, and applications (Vol. 10). Springer Science \& Business Media.

Lawrence, K.L. 2012. ANSYS workbench tutorial release 14. SDC publications.

Lazaridis, G., Vavliakis, E., Pennos, C. 2005. Temporal earth pyramids in caves. An example from Zesta Nera cave of Sidirokastro, Serres (Macedonia, Greece). School of Geology, Aristotle University (A.U. TH.), 54124 Thessaloniki. Hellenic Speleological Society. 14 ${ }^{\text {th }}$ International Congress of Speleology.

Lee, H.H. 2015. Finite Element Simulation with ANSYS Workbench 16. SDC publications.

Logan, D.L. 2011. A first course in the finite element method. Cengage Learning.

López, J.O., Reyes, L.V., Vera, C.O. 2017. Structural health assessment of a R/C building in the coastal area of Concepción, Chile. Procedia Engineering 199, 2214-2219. https://doi. org/10.1016/j.proeng.2017.09.185.

Lorenzoni, F. 2013. Integrated methodologies based on structural health monitoring for the protection of cultural heritage buildings. Doctoral dissertation, University of Trento.

Magalhães, F.M.R.L. 2012. Identificação modal estocástica para validação experimental de modelos numéricos. Faculdade de Engenharia, Universidade do Porto, Porto, 208 pp.

Mahmoudzadeh, M.R., Francés, A.P., Lubczynski, M., Lambot, S. 2012. Using ground penetrating radar to investigate the water table depth in weathered granites-Sardon case study, Spain. Journal of Applied Geophysics 79, 17-26. https://doi.org/10.1016/j.jappgeo.2011.12.009.

Marchamalo, M., Galán, D., Sánchez, J.A., Martínez, R. 2011. La Tecnología DGPS en la construcción: Control de movimientos en grandes estructuras. Informes de la Construcción 63 (522), 93-102. https://doi.org/10.3989/ic.10.008.

Martínez-Martínez, J., Benavente, D., García-del-Cura, M.A. 2012. Comparison of the static and dynamic elastic modulus in carbonate rocks. Bulletin of Engineering Geology and the Environment 71 (2), 263-268. https://doi.org/10.1007/s10064-011-0399-y.

Masciotta, M.G., Roque, J.C, Ramos, L.F., Lourenço, P.B. 2016. A multidisciplinary approach to assess the health state of heritage structures: The case study of the Church of Monastery of Jerónimos in Lisbon. Construction and Building Materials 116, 169-187. https://doi. org/10.1016/j.conbuildmat.2016.04.146.

Monteverde, A. 1946. Origen del Puente del Inca. Revista La Ingeniería 866, 775-791.

Monteverde, A. 1967. Preservación del Puente del Inca. Revista Caminos 34 (295), 33-36.

Najibi, A.R., Ghafoori, M., Lashkaripour, G.R., Asef, M.R. 2015. Empirical relations between strength and static and dynamic elastic properties of Asmari and Sarvak limestones, two main oil reservoirs in Iran. Journal of Petroleum Science and Engineering 126, 78-82.

Nicod, J. 1981. Répartition, classification, relation avec les milieux karstiques et karstification. Bulletin de l'Association des Géographes Françaises, 479-480, 181-187. https://doi. org/10.1016/j.petrol.2014.12.010.

Parloo, E. 2003. Application of frequency-domain system identification techniques in the field of operational modal analysis. Vrije Universiteit Brussel, Belgium. 
Pentecost, A. 2005. Travertine. Springer Science \& Business Media.

Pérez González, M.J. 2010. Análisis tensodeformacional de un tornillo. Master Thesis, Universidad Carlos III de Madrid, Departamento de Mecánica de Medios Continuos y Teoría de Estructuras.

Polat, S. 2011. Türkiye'de traverten oluşumu, yayiliş alani ve korunmasi. Marmara Coğrafya Dergisi, 23 pp.

Potts, D.M.,Zdravković, L. 2001. Finite element analysis in geotechnical engineering: application (2). Thomas Telford.

Ramos, V.A. 1993. Geología y estructura de Puente del Inca y el control tectónico de sus aguas termales. Simposio sobre puente del Inca. $12^{\circ}$ Congreso Geológico Argentino y $2^{\circ}$ Congreso de Exploración de Hidrocarburos, Actas 5, Buenos Aires, pp. 8-19.

Ren, W.X, Peng, X.L. 2005. Baseline finite element modeling of a large span cable-stayed bridge through field ambient vibration tests. Computers \& Structures 83 (8-9), 536-550. https://doi. org/10.1016/j.compstruc.2004.11.013.

Ribeiro, D., Calçada, R., Delgado, R., Brehm, M., Zabel, V. 2012. Finite element model updating of a bowstring-arch railway bridge based on experimental modal parameters. Engineering Structures 40, 413-435. https://doi.org/10.1016/j.engstruct.2012.03.013.

Rimoldi, H. 1993. Puente del Inca un monumento natural comprometido. XII Congreso Geológico Argentino. II Congreso de Exploración de Hidrocarburos. Actas TV, pp. 20-23.

Rodrigues, J., Brincker, R., Andersen, P. 2004. Improvement of frequency domain output only modal identification from the application of the Random Decrement Technique. In: Proceedings of IMAC-22: A Conference on Structural Dynamics, Society for Experimental Mechanics, Dearborn, MI, pp. 92-100.

Rubio, H.A., Santilli, C.A., Salomón, M.A. 1993. Puente del Inca: Restauración y preservación. $12^{\circ}$ Congreso Geológico Argentino y $2^{\circ}$ Congreso de Exploración de Hidrocarburos, Actas 5, Buenos Aires, pp. 20-23.

Salvini, R., Francioni, M., Riccucci, S., Fantozzi, P.L., Bonciani, F., Mancini, S. 2011. Stability analysis of "Grotta delle Felci" Cliff (Capri Island, Italy): structural, engineering-geological, photogrammetric surveys and laser scanning. Bulletin of Engineering Geology and the Environment 70 (4), 549-557. https://doi.org/10.1007/s10064-011-0350-2.

Sekelj, T. 1944. Tempestad sobre el Aconcagua: 22-25. Buenos Aires.

Sequera Gutiérrez, D.A., Solano Rodríguez, L.F. 2013. Algoritmo para la calibración de modelos estructurales en elementos finitos de puentes usando Ansys. Bachelor Thesis, Pontificia Universidad Javeriana, Facultad de Ingeniería, Bogotá.

Seyfried, M.S., Murdock, M.D. 2004. Measurement of Soil Water Content with a 50-MHz Soil Dielectric Sensor. Soil Science Society of America Journal Abstract - DIVISION S-1-SOIL PHYSICS, 68 (2), 394-403. https://doi.org/ 10.2136/sssaj2004.3940.

Shen, W., Hao, Q., Mak, H., Neelamkavil, J., Xie, H., Dickinson, J., Thomas, R., Pardasani, A., Xue, H. 2010. Systems integration and collaboration in architecture, engineering, construction, and facilities management: A review. Advanced engineering informatics 24 (2), 196-207. https://doi.org/10.1016/j.aei.2009.09.001.

Shervais, K. (UNAVCO). 2015. Structure from motion introductory guide. Version Oct 22, 2015.

Slingerland, R., Kump, L. 2011. Mathematical modeling of Earth's dynamical systems: A primer. Princeton University Press.

Smith, M.W., Carrivick, J.L., Quincey, D.J. 2015. Structure from motion photogrammetry in Physical Geography. Progress in Physical Geography 40 (2), 247-275. https://doi. org/10.1177/0309133315615805.

Takasu, T. 2009. RTKLIB: open source program package for RTK-GPS. FOSS4G 2009, Tokyo, Japan. 
To,T., Nguyen,D., Tran, G. 2015. Automated 3D architecture reconstruction from photogrammetric structure-and-motion: A case study of the One Pilla pagoda, Hanoi, Vienam. The International Archives of Photogrammetry, Remote Sensing and Spatial Information Sciences 40 (7), 1425. https://doi.org/10.5194/isprsarchives-XL-7-W3-1425-2015.

Veysey, J., Fouke, B.W., Kandianis, M.T., Schickel, T.J., Johnson, R.W., Goldenfeld, N. 2008. Reconstruction of water temperature, $\mathrm{pH}$, and flux of ancient hot springs from travertine depositional facies. Journal of Sedimentary Research 78 (2), 69-76. https://doi.org/10.2110/ jsr.2008.013.

Welch, P.D. 1967. The use of Fast Fourier Transform for the estimation of power spectra: a method based on time averaging over short modified periodograms, IEEE Transaction on Audio and Electro-Acoustics, AU-15 (2).

Westoby, M.J., Brasington, J., Glasser, N.F., Hambrey, M.J., Reynolds, J.M. 2012. Structurefrom-motion photogrammetry: A low-cost, effective tool for geoscience applications. Geomorphology 179, 300-314. https://doi.org/10.1016/j.geomorph.2012.08.021.

Wiese, P.R., John, P. 2003. Engineering design in the multi-discipline era: a systems approach. Wiley.

Wilson, J.M.B. 2013. Patrimonio geológico del proyecto geoparque Cajón del Maipo (Región Metropolitana-Chile). Tesis de Maestría, Escola de Ciências, Universidade do Minho, 143 pp.

Wu, C. 2007. SiftGPU: A GPU Implementation of scale invariant feature transform (SIFT), http:// cs.unc.edu/ ccwu/siftgpu, 2007.

Wu, C. 2011. Visual SFM: A visual structure from motion system. http://ccwu.me/vsfm/

Wu, C., Agarwal, S., Curless, B., Seitz, S.M. 2011. Multicore Bundle adjustment. In: Computer vision and pattern recognition (CVPR), 2011 IEEE Conference on: 3057-3064. IEEE.

$\mathrm{Wu}, \mathrm{C} .2013$. Towards linear-time incremental structure from motion. In: 2013 International Conference on 3DVision-3DV2013,pp.127-134.IEEE.https://doi.org/10.1109/3DV.2013.25.

Zong, Z., Lin, X., Niu, J. 2015. Finite element model validation of bridge based on structural health monitoring Part I: Response surface-based finite element model updating. Journal of Traffic and Transportation Engineering 2 (4), 258-278. https://doi.org/10.1016/j.jtte.2015.06.001. 